University of New Hampshire

University of New Hampshire Scholars' Repository

Applied Engineering and Sciences Scholarship

Applied Engineering and Sciences

7-9-2016

\title{
Latin American perspectives to internationalize undergraduate information technology education
}

\author{
Mihaela C. Sabin \\ University of New Hampshire, Manchester, mihaela.sabin@unh.edu \\ Barbara Viola \\ Viotech Solutions Inc \\ John Impagliazzo \\ Hofstra University \\ Renzo Angles \\ Universidad de Talca \\ Mariela Curiel \\ Pontificia Universidad Javeriana \\ Follow this and additional works at: https://scholars.unh.edu/unhmcis_facpub \\ Sermexteptse for additional authors \\ (c) 2016, Association for Computing Machinery, Inc. This is the author's version of the work. It is posted here for your \\ personal use. Not for redistribution. The definitive Version of Record was published in Proceedings of the 2016 \\ ITiCSE Working Group Reports, https://dx.doi.org/10.1145/3024906.3029847.

\section{Recommended Citation} \\ Mihaela Sabin, Barbara Viola, John Impagliazzo, Renzo Angles, Mariela Curiel, Paul Leger, Jorge Murillo, \\ Hern'an Nina, Jos'e Antonio Pow-Sang, and Ignacio Trejos, Latin american perspectives to \\ internationalize undergraduate information technology education, Proceedings of the 2016 ITiCSE \\ Working Group Reports, ITiCSE'16, ACM, 2016, pp. 1-22.
}

This Article is brought to you for free and open access by the Applied Engineering and Sciences at University of New Hampshire Scholars' Repository. It has been accepted for inclusion in Applied Engineering and Sciences Scholarship by an authorized administrator of University of New Hampshire Scholars' Repository. For more information, please contact Scholarly.Communication@unh.edu. 


\section{Authors}

Mihaela C. Sabin, Barbara Viola, John Impagliazzo, Renzo Angles, Mariela Curiel, Paul Leger, Jorge Murillo, Hernan Nina, Jose Antonio Pow-Sang, and Ignacio Trejos 


\section{Latin American Perspectives to Internationalize Undergraduate Information Technology Education}

\author{
Mihaela Sabin ${ }^{1}$ \\ Co-Leader \\ Computing Technology \\ University of New Hampshire \\ Manchester, NH 03101 USA \\ $+1.603 .641 .4144$ \\ mihaela.sabin@unh.edu \\ Renzo Angles \\ Dept.of Computer Science \\ Universidad de Talca \\ Camino Los Niches Km. 1 \\ Curicó, Chile \\ +56752201711 \\ rangles@utalca.cl \\ Jorge Murillo ${ }^{3}$ \\ IEEE Computer Society \\ Prof. \& Educ. Activities Board \\ Heredia, Costa Rica 40101 \\ $+5068330-5337$ \\ jorgemurillo2011@gmail.com \\ jorge.murillo.cr@ieee.org
}

\author{
Barbara Viola ${ }^{1,2}$ \\ Co-Leader \\ Viotech Solutions Inc. \\ 1111 Route 110, Suite 362 \\ Farmingdale, NY 11735 USA \\ $+1.631 .630 .4640$ \\ bviola@viotechsolutions.com \\ Mariela Curiel \\ Pontificia Universidad Javeriana \\ Carrera 7, No 40-62 \\ Bogotá, Colombia \\ +5713208320 \\ mcuriel@javeriana.edu.co
}

\author{
John Impagliazzo ${ }^{1}$ \\ Co-Leader \\ Engineering and Applied Sciences \\ Hofstra University \\ Hempstead, New York 11549 USA \\ $+1.631 .513 .2833$ \\ john.impagliazzo@hofstra.edu \\ Paul Leger \\ Universidad Católica del Norte \\ Larrondo \#1281 \\ Coquimbo, Chile \\ +56512209839 \\ pleger@ucn.cl
}

\author{
José Antonio Pow-Sang ${ }^{1,3}$ \\ Pontificia Universidad Católica del Perú \\ Av. Universitaria 1801, San Miguel \\ Lima, Peru \\ $+511626-2000$ \\ japowsang@pucp.edu.pe
}

1: Association for Computing Machinery (ACM)
2: Association of Information Technology Professionals
(AITP)
3: Institute of Electrical and Electronics Engineers
Computer Society (IEEE CS)

\begin{abstract}
The computing education community expects modern curricular guidelines for information technology (IT) undergraduate degree programs by 2017 . The authors of this work focus on eliciting and analyzing Latin American academic and industry perspectives on IT undergraduate education. The objective is to ensure that the IT curricular framework in the IT2017 report articulates the relationship between academic preparation and the work environment of IT graduates in light of current technological and educational trends in Latin America and elsewhere. Activities focus on soliciting and analyzing survey data collected from institutions and consortia in IT education and IT professional and educational societies in Latin America; these activities also include garnering the expertise of the authors. Findings show that IT degree programs are making progress in bridging the academic-industry gap, but more work remains.
\end{abstract}

\section{CCS Concepts}

$\mathrm{CCS} \rightarrow$ Social and professional topics $\rightarrow$ Professional topics $\rightarrow$ Computing education $\rightarrow$ Computing education programs $\rightarrow$ Information technology education

\section{Keywords}

Information technology, IT, IT in Latin America, academia and industry, Latino IT curriculum

\section{INTRODUCTION}

The research reported in this paper is an ongoing development of the ACM/IEEE effort to produce the IT2017 Curriculum Guidelines for Undergraduate Degree Programs in Information Technology report ${ }^{1}$, currently version 0.61 at the time of this writing. The effort is a complete update of the IT2008 report of similar title [3]. The authors, part of Working Group 1 at ITiCSE 2016, focused on being forward thinking to capture both the current and future changes in IT education, particularly as they relate to Latin America.

To address the very broad issue of multinational perspectives on IT education, the work in this paper centers on three research questions. They are:

1. What is the collaborative nature of IT between academia and industry in Latin America?

\footnotetext{
http://it2017.acm.org

${ }^{2}$ https://www.comptia.org/
} 
2. What is the status of IT professional practice and assessment in Latin America and what do research results tell us?

3. What is the current situation of IT degree programs in Latin America and based on the findings above, what would be an ideal futuristic IT program for Latin America?

\subsection{Information Technology and its Meaning}

The term 'information technology' (IT) means different things for different stakeholders. These stakeholders include academic institutions, industry and business sectors, government agencies, and professional and scientific societies. The mix of multiple stakeholders is compounded by geographic and local contexts. Furthermore, an ongoing debate among computing disciplines holds different views of what IT is and whether the IT discipline is specifically distinctive from other computing disciplines or it should define itself as a broad field of computing. In attempting to answer the research questions, even more questions emerged, which we elaborated on further in this research study.

Originally, as a technology economic sector IT consisted of very specialized and expensive computing and communications technologies, available to a relatively small portion of society. Consequently, early academic disciplines in the IT field included electrical engineering, mathematics, information systems management, and computer science. Today, the term 'information technology' has evolved to capture a fast-changing field that impacts every economic sector and aspect of society worldwide. A modern meaning of IT should include perspectives of globalization; multinational, multicultural and multidisciplinary teamwork; innovative frameworks, and regulations; professional practices; and the importance of non-cognitive skills that encompass personal, social, and emotional intelligence skills.

In this research study, we have adopted and used the meaning of the following definition [3]:

"Information Technology (IT) in its broadest sense encompasses all aspects of computing technology. IT, as an academic discipline, is concerned with issues related to advocating for users and meeting their needs within an organizational and societal context through the selection, creation, application, integration and administration of computing technologies."

\subsection{Brief History of Computing and IT Education in Latin America}

The history of computing in Latin America started at the end of the 1950s when the first computers were introduced in countries such as Mexico, Brazil, Colombia, and Chile. According to Ivan da Costa [27], the Latin American history in computing was influenced by relationships with the United States, Western Europe, and other developed nations, plus the European roots (i.e., Spain and Portugal) of all Latin American countries. Additionally, economic, political, and social issues occurring in each country influenced the development of computing-related projects and education programs.

Because of external factors, the evolution of computing and IT education in Latin America varies significantly among countries. Mexico entered into the computing technology era when the National Autonomous University of Mexico (UNAM) acquired its first computer in 1958. The National Polytechnic Institute was the first Mexican university to offer bachelor's degrees in computing engineering in 1965. After that, UNAM started to teach computer engineering as well as the first computer science programs [29]. In the case of Argentina, the history began in 1960 with the creation of the "Instituto de Cálculo" inside the School of Science at Universidad de Buenos Aires [11]. Two years later, this institute created the first computer science program in Latin America aiming to educate "scientists" assistants" [43]. This program was used as a basis for the Central University of Venezuela to create the first degree in computer science, with a solid mathematical background and theoretical computer science [40].

The computer-related activities in Chile began in the early 1960s around two main tasks: information systems and scientific computation [4]. The first computing curriculum offered in Chile was a three-year program in computer programming at the Universidad de Chile in 1968 [7]. Computing education started in Costa Rica in the 1960 s, when two local players in the IT industry, namely IBM and Burroughs, started offering training courses in programming and system administration to engineering and science students and graduates to develop local capabilities for operating and developing their clients' computing systems. University education started in the 1970s at two public universities: University of Costa Rica (1973) and Costa Rica Institute of Technology (1976).

Computing education in Colombia started at two universities, Universidad Nacional and Universidad de Los Andes, with the arrival of the first two IBM 650 computers. In 1966, the Universidad Nacional created the first Master Program in Computer Science in Latin America [52]. Brazil started its history in computing in the late 1960s with the National Computer Policy, a special industrial and technological policy for computer manufacturing. Consequently, during the 1970s several universities established laboratories and courses on digital techniques and computer programming. In Peru, computing education began with the introduction of the term "ingeniero de sistemas" (systems engineer); this term was used by companies like IBM to describe a job in industry concerning the management of computing equipment and systems. The first program for systems engineering was created in mid-1970s. Currently, Peruvian universities offer ten different programs related to computing, software, and systems.

\subsection{IT in Latin America}

In Latin America, many IT transitions have occurred over the past two decades. For example, Mexico has reached a more important role in the growing world industry of IT by including a wide range of products to become "the relevant variable of the knowledge society and the main driver of our times' technological and communications revolution" [72]. After many years of building trade barriers to protect its industry, Brazil invested heavily in building its scientific and technological research and development capabilities - via doctoral scholarships and sponsorship of regional and national research laboratories. Nowadays Brazil considers IT as a way to create a competitive and innovative environment to promote economic development of the country.

Governments of many developing countries support IT initiatives and have made large capital investments in IT infrastructure. Chile's government, for example, has already integrated IT in education, business and government. Smaller countries, such as Costa Rica and Uruguay, reached the Inter-American Development and its Multilateral Investment Fund for loans targeted at strengthening their software industries' export capabilities through improving quality and productivity in companies, updating university curricula, building institutional 
competencies, and fostering innovation and entrepreneurial initiatives $[41,53,54,55]$.

\section{PRIOR RESEARCH}

To capture the variety of factors on IT education, the steering committee members of the IT2017 task group led the formation of the Working Group 6 at 2015 ITiCSE. The working group examined multinational perspectives from academia and industry on the development of curriculum guidelines for a rigorous, high quality bachelor's degree programs in information technology [65]. Three research lines of inquiry guided the working group's study: (1) commonalities and differences among IT curricular frameworks in academic institutions worldwide; (2) educational pathways into IT degree programs; (3) indicators and predictors of the future of IT. The working group members complemented extensive literature review and their own multinational insights with the analysis of survey data of IT faculty members and professional IT industry leaders.

Administered by the ACM in Spring 2015, the faculty survey reached out to over 16,000 computing faculty in four-year undergraduate programs worldwide. A total of 597 responded (about 3.8\% response rate). The survey asked 16 questions with a mix of multiple choice and free form items in three areas of interest: IT program information (geographic location, name of hosting department, number of graduates and percentage of graduating students who pursued graduate studies), IT curricular framework (IT domains, relevant math and science subjects, internship experience, and size of the IT component of the full degree program), and sources of external student transfers (two or three-year schools, industry-university articulations, life experience credits).

The Association for Information Technology Professionals (AITP) joined efforts with the IT2017 task group and administered an industry survey of its membership. The survey asked seven questions: six questions were adopted from the faculty survey for an industry audience: IT organization information (location, name, and number of employees) and IT curricular framework (IT domains and relevant math and science subjects); one question was new and added to gather information about top skill sets required of IT graduates in 2020s. Leaders of AITP distributed the survey to almost 2,000 members. A total of 91 members responded ( $5 \%$ response rate), with 90 from the United States.

Research findings of the working group informed the development of the IT2017 report as follows. First, many meanings of IT exist depending on academia, industry, and geographic location. The content of an academic degree in a particular country often reflects the needs of industry in that area. human computer interaction was proportionally more preferred outside the US, while information assurance and cybersecurity and system administration and maintenance were proportional44ly more favored by responses from the US.

Curriculum configuration weighed competing factors, reconciling mathematical rigor, subject matter depth, degree program breadth, and relevance of experiential learning and prior academic experiences. Cultural expectations vary with geography. The analysis showed that in general IT programs outside the United States are more rigorous, more intense, and more challenging to students than programs in the United States are. Effective curriculum guidelines should find some balance among these factors to facilitate international implementation and adoption.
Thus it is important to prepare IT graduates to work with diverse applications and in diverse professions as IT is an enabler that promises to generate greater growth in the future. Secondly, survey analysis showed that there was agreement between industry and academia on science requirements and highly close agreement on math requirements, with statistics being a top subject of choice for math that is necessary in all IT degree programs. IT curricular domains of importance showed overall a general positive agreement. The top knowledge areas for which industry and academia reached agreement were cybersecurity and information management, and the two IT domains showing the most polarized support were Programming (favored by academia) and cybersecurity and Digital Forensics (favored by industry). There were significant differences between IT degree programs in the US and outside the US with regard to the program's IT technical component. Non-US IT programs were more robust in their technical components and provided a normal pathway to graduate study. Other differences manifested in the educational pathways to a bachelor's degree. US IT programs provided more transfers from many sources, but even more transfers occurred from two-year and three-year technical programs. In non-US countries, transfers to baccalaureate programs were few due to very limited pathways and conformity to local regulations. Lastly, the future of IT remains as fluid as expected. Notwithstanding, it was intensely clear from the research that soft (people) skills were as important as technical skills and that project management was an important professional skill.

The question of how geographical location and cultural context of computing departments might affect the successful implementation of the IT curriculum guidelines was further pursued by additional data analysis of the Spring 2015 faculty survey conducted by ACM. Examination of the faculty survey responses emphasized international parallels and contrasts in four areas of interest: curriculum content, curriculum configuration of IT degree programs, transfer pathways into undergraduate IT degree programs, and English language names used to identify IT degree programs in international computing education [65].

In the curriculum content area, findings showed a high degree of agreement between United States and non-United States respondents' importance ranking of the 17 prompted IT domains. Nine of the domains received strongly similar support internationally, and six of those nine domains were voted among the most important domains overall: big data, programming, cloud computing, information management, web systems and technologies, and networking. Domains with slightly dissimilar support or lower rankings will need more attention from curriculum guideline authors. There were three areas with relatively disproportionate support from one group over another:

The survey data revealed that six distinct program names accounted for more than half of all degree program name uses: computer science, information technology, information systems, computer engineering, software engineering, and informatics. Five names match the five ACM computing discipline names. Computer science and information technology dominate the name space $(69 \%$ uses). The international similarities in naming terms can be useful when composing recommendations for global use.

Despite efforts to prepare college students adequately for professional careers, gaps persist between student and employer perceptions of student preparation for their future careers. The most recent national surveys commissioned by the American Association of Colleges and Universities [37] found that students and employers are alike in their perception of how well prepared 
students are to stay current with new technologies. However, in other key areas, such as communication, applying knowledge and skills to real world situations, critical thinking, and solving complex problems, students overestimate their preparation.

Further analysis of the IT2017 survey data gained more insights into what the IT discipline means within the computing profession to academia and industry [67]. Analysis of responses from about two hundred US faculty members and from ninety US industry IT professionals focused on comparing faculty and industry preferences in mathematics, IT domain areas, and student workplace skill sets.

The study found a reasonable degree of agreement in the math and IT curricular content, such as statistics, web systems and technologies, and information management. There were, however, some contrasts. Broadly speaking, and predictably, faculty placed higher value on curriculum content that is useful for learning more (such as discrete mathematics and programming, for example), while industry gave more weight to areas immediately applicable to producing more (like business mathematics and cybersecurity). There was no surprise that two skill sets did especially well, project management and soft skills. Domain independent rather than peculiar to computing disciplines, these transferable skills have been highly valued in industry surveys $[10,37]$.

The study's results reassured computing faculty and industry professionals that ongoing dialog and collaboration in curriculum development is mutually beneficial. Periodic updates of computing curricula by ACM and partnering professional societies rely on industry feedback. Academic programs integrate a variety of experiential learning opportunities through internships and industry-sponsored projects. Faculty and industry professionals alike have the responsibility to continue to communicate to each other the relevance of what they do the best in their respective domains, and create and support more effective pathways to transfer content mastery into professional practices.

\section{ANALYSIS OF IT EDUCATION IN LATIN AMERICA}

It is a fact that both teachers and students are the main actors in research, education and scholarship inside the academic environment. In the case of IT, employers of IT talent also plays a very important role. In a typical configuration, academia acts as a provider of human resources to the IT industry sector. A middlelevel configuration could imply that IT industry (encompassing private and public sector, including government and nonprofit/non-government organizations) provides real business needs that drive research in academia.

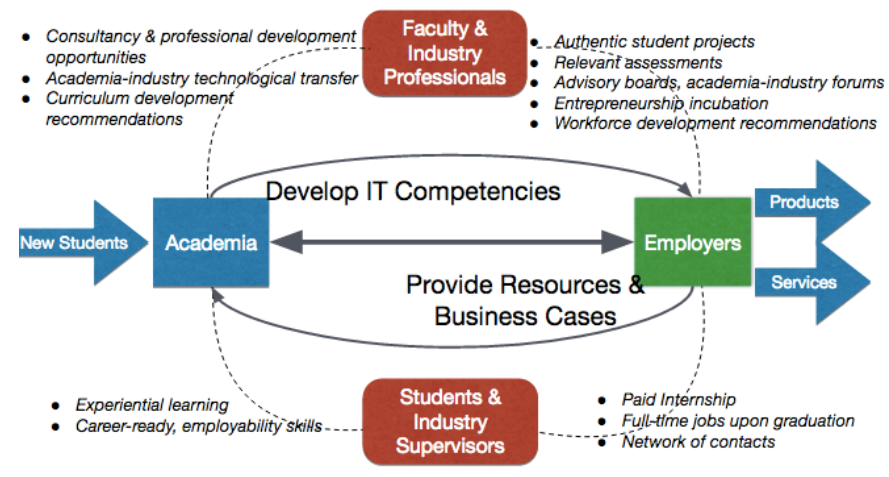

Figure 3.1 IT2017 Academia-employer value chain diagram
However, an ideal configuration models a stronger and dynamic interaction between academia and industry. Such interaction means a value chain between academia and employers of IT graduates (Figure 3.1). The interchange between developing IT competencies and provision of business cases and resources is conducted collaboratively with faculty, industry professionals, students, and industry supervisors of student work experience. Such collaborations should be supported with high-quality education from academia and economic investment from industry.

In this section we analyze the status of IT education in Latin America based on the academy-employer value chain described above. Our analysis is divided in four main issues: the IT skills set gap (i.e. unavailability of sufficient qualified candidates to fulfill open positions), the collaboration between academia and workplace, the scope of IT professional practice, and the IT curricula to be found at Latin America universities. For each of the above issues we look for strengths, weaknesses, opportunities and threats (i.e. the basic elements of a SWOT analysis). The findings of our analysis are summarized as follows:

\section{IT skills set gap}

a. Strengths: Essential skills are usually covered by academia; Industry is trying to close the gap with internships and investment; the problem has grown in importance and is being addressed in some Latin American countries.

b. Weaknesses: It is a current problem in richer nations and developing countries; few universities have identified or understood IT as a new academic discipline; few employers are aware of IT curricula recommendations; educational institutions are delayed with respect to the needs of the industry (some skills developed in academia are not useful for industry, whereas other important skills are not well covered); non-cognitive, intrapersonal and interpersonal skills (so called "soft" skills) are difficult to "teach" in academia.

c. Opportunities: New and emerging IT market skills.

d. Threats: The IT market is a source of emerging skills; demand of computing skills significantly exceeds supply; industry could teach technical people with specific skills; good technical programs are created for demanding jobs; academic regulations make difficult the adaptations to the job market.

2. Academia-workplace collaboration

a. Strengths: Existence of advisory boards; existence of academia-industry forums; collaboration with technology vendors; continuing education and industry; local internships are easy to implement and low-cost for industry.

b. Weaknesses: Restricted actions of industry representatives; faculty mostly with CS or IS academic background.

c. Opportunities: Replication of university-industry forums; student-industry and professor-industry mentorships; university-industry technological transfer (in both ways); development of IT capabilities in industry.

d. Threats: Collaboration restricted by industry or university maturity.

\section{IT Professional practice \& assessment}

a. Strengths: National and international accreditations; accreditation systems consider the participation of industry representatives; internships are highly encouraged as a graduation requirement; capstone projects encourage 
interdisciplinary and teamwork skills, and confronting projects with real constraints.

b. Weaknesses: Accreditation cannot be mandatory and can require a long-time effort; internships cannot be mandatory in many programs of study; international internships are difficult to implement; internship duration could be insufficient to satisfy industry requirements; difficulties to implement capstone projects; low quality of capstone project deliverables; challenges with integrating capstone projects in research and entrepreneurial endeavors; ethics courses are frequently too general, lacking IT-specific content.

c. Opportunities: Extended adoption and enhancement of accreditation processes; accredited programs could attract more students; academic recognition of faculty work through internship supervision and mentoring; students increase possibility of being hired upon graduation.

d. Threats: Accreditation influenced by government regulations.

4. IT curricula analysis

a. Strengths: IT-related programs have strong foundational math and science curriculum requirements.

b. Weaknesses: Curricula not aligned with the IT discipline; ITrelated programs have different names and do not reflect the ACM/IEEE-CS curriculum recommendations; low mastery of English; entrepreneurship is not usually incorporated in IT-related programs.

c. Opportunities: Industry-relevant certifications; laws do not impose non-IT courses.

d. Threats: Political, economic and social instability; educational regulations impede responsive adaptations.

The details of our analysis are presented next.

\subsection{The IT Skills Set Gap}

The World Economic Forum, in its report entitled 'The Future of Jobs' [80] asserts:

\begin{abstract}
"Disruptive changes to business models will have a profound impact on the employment landscape over the coming years. Many of the major drivers of transformation currently affecting global industries are expected to have a significant impact on jobs, ranging from significant job creation to job displacement, and from heightened labour productivity to widening skills gaps. In many industries and countries, the most in-demand occupations or specialties did not exist 10 or even five years ago, and the pace of change is set to accelerate.".
\end{abstract}

Digital information and communications technologies have been one of the major drivers of a worldwide transformation impacting practically all human endeavors, and have been, within themselves, evolving at a very fast pace during the last six decades. The IT skills gap refers to the unavailability of sufficient qualified candidates to fulfill open positions in IT-related occupations. The problem has been reported in richer nations and developing countries $[25,32,47]$, and manifests itself in manifold ways:

- Insufficient numbers of educated persons to fulfill job openings in certain positions;

- Candidates who are inadequately prepared for IT position;

- New occupations spawn from technological change and innovation, plus new business models and services;

- Need for retraining or retooling existing personnel in order to keep them abreast of newly acquired technologies;
- Requirement to maintain and keep operational information systems that are built on older technology no longer being taught at universities;

- Underrepresentation of women and ethnic minorities in the IT workforce impairs diversity, consequently impacting negatively creativity, innovation, productivity and prosperity;

- Delay of educational institutions in creating and innovating curricula to prepare the future IT workforce and developing programs to retrain those already employed.

The IT skills gap worldwide has been extensively surveyed, notably by CompTIA ${ }^{2}$, but not specifically in Latin America [23, 24, 25]. Cisco Systems has commissioned research to a leading marketing intelligence global provider, International Data Corporation (IDC), three times so far, aiming at understanding the skills gap in Latin America related to networking, defined as "the skills of those people needed to plan, design, manage and support the networking technologies in an organization." $[20,38,39]$. IDC estimated a shortage of approximately 296,200 full-time equivalent (FTE) professionals with networking skills across Latin America by 2015 [38]. In 2015, IDC interviewed 760 employers' representatives in ten Latin American countries: Argentina, Brazil, Chile, Colombia, Costa Rica, Dominican Republic, Ecuador, Mexico, Peru, and Venezuela. In their recently published research report [39s], IDC revised their original IT skills shortage estimates for 2015 to 474,400 FTEs, forecasting a slight decrease to 449,152 FTEs by 2019 .

IDC studies shed light into the evolution of the networking technology skills gap within IT. They divide networking skills between 'essential' (routing and switching, security, wireless, voice over IP, unified communications) and 'emerging' (video, cloud, mobility, data center and virtualization, big data, cybersecurity, Internet of Things, and software development) [39]. These reports highlight the complexity and qualitative aspects of the gap, as expressed by employers:

- Cross-technology skills

- Vendor certifications

- Impact of managed (outsourced) services on the networkingskilled professional development

- Non-technical skills.

In coincidence with the findings of the IT2017 project communicated in [65], the 2015 IDC study [39] reports that nontechnical skills are also required by $85 \%$ of the companies hiring network professionals in Latin America. "Proficiency in English, team work, problem solving, creativity and innovation, and communication skills represent the most valued by companies. Even when project management and cross-technology skills are still considered as key, they are considered very important only by $35 \%$ of companies, relatively low when compared with English and teamwork, at $63 \%$ and $55 \%$ respectively".

There is a perception in many Latin American countries that demand of computing skills significantly exceeds supply. Yet, numbers do not offer a complete explanation. Consider:

- The range of skills needed for some positions does not exist readily in the labor marketplace (e.g., storage, digital forensics, data scientists, cloud computing, and virtualization);

\footnotetext{
${ }^{2}$ https://www.comptia.org/
} 
- There is large variability in the quality of the preparation of IT graduates in terms of breadth of knowledge, depth of expertise, relevance of experience, certification of abilities, mastery of domain, and foundational academic education.

Different circumstances in academia, among students, and in the workplace might explain the existing IT skills gap in Latin America:

- Few universities have identified or understood IT as a new academic discipline, or lag behind in catering to the appearance of new occupations or skill sets;

- Students tend to replace university degrees with vocational training, certifications, or short technical specializations;

- Employers reach out to people who have not completed an undergraduate or graduate college degree;

- Employers invest heavily in training new recruits to learn technologies, methods, standards, and processes, in order to be productive on the job.

To compound the situation, Latin American universities often face strict regulations and slow processes that impede their development of academic programs addressing new computing disciplines such as IT, networking, cybersecurity, or interactive digital technologies. In many cases, computing programs at Latin American universities have developed academically within the traditions of engineering education that set standards for coverage of subjects in mathematics and physics, or require five or six years of studies to complete a nationally-recognized university degree. By comparison to North America, two-year degrees are not particularly well-regarded in most Latin American countries, as they are perceived of a lower 'prestige' or quality. All this also adds difficulty to reduce the IT skills set gap.

Few employers are aware of computing curricula recommendations such as Computing Curricula 2005 [2] or IT2008 Report [3]. Many managers use their own university education experience as a frame of reference, when computing curricula used to be more general and were adequate to meet the less diverse skill sets needed at that time. Although they acknowledge the evolution of the skills and new developments in academia, employers $d$ have only recently collaborated with universities to address the computing skills gap in the geographies in which they operate (this applies to multinationals operating worldwide too) [46].

Each Latin American country addresses its situation in different ways. Some countries consider workforce development as a strategic matter, have established collaborative arrangements between universities (and other academic institutions) and employers (workplaces, that can be private enterprises or public organizations), and foster the monitoring of skill sets required by employers and the offerings provided by educational institutions in their territories.

\subsection{Academia-Workplace Collaborations}

Since ACM published the IT2008 guidelines [3], there has been a monumental change within business and industry. In a very real sense, the success of a business now depends on skilled graduates that they are able to recruit and further train to develop IT skills needed within their companies. Gaining and developing the proper IT talent is essential to a company's viability and ongoing success, and determines how quickly they can solve business problems, adapt to change, innovate and, ultimately, prosper. The question is how might universities help in this endeavor? It is more important than ever that students graduating with technology degrees are able to adapt into the workplace and meet the needs of industry. It is critically relevant to industry that university graduate students enter the workforce and start contributing to the success of their companies within a short timeframe. Therefore, academia should assure that IT curriculum is in line with industry requirements.

Academia and workplace collaborations vary from country to country in Latin America. Although some countries have universities with centuries of tradition, Latin American university education in engineering and technology has evolved in a way that kept universities quite distant from industry. Political instability and social unrest have impeded collaboration in several countries; for instance, many public universities aligned ideologically with the 'left' and opposed 'right-wing' governments and the productive sector (though this has changed dramatically since the 1990s). Industry is seeking talent in universities from technological fields and, concurrently, pragmatic universities do approach employers (sometimes organized as chambers or industry associations) to understand the evolution of the skill set they need in their workforce.

\subsubsection{Advisory Boards}

Some universities in Latin America do have advisory boards that incorporate representatives from industry, but this practice is not generalized. The scope of advisory boards ranges from universityto department- and program-level advising and consultancy. For example, Tecnológico de Monterrey (Mexico), a prestigious nonprofit technological and business university in the Norteast part of Mexico, was founded by a group of industrial and business people from the state of Monterrey, led by Eugenio Garza Sada. Their governing board has members from diverse industries: food and beverages, airlines, manufacturing, software, building and construction, automotive, information technology, metal transformation, electrical, petrochemical, real-estate, banking, commerce and retail, building materials, telecommunications, and internet. Schools there do have advisory boards with members from their related disciplines.

In Costa Rica few universities have active industrial advisory boards. For instance, in spite of its constituting law foreseeing the establishment of advisory boards including industry representatives for every academic program, Tecnológico de Costa Rica (TEC) has seldom implemented them, with the exception of computing, which ran an advisory board from 1986 to 1990. Universidad Cenfotec, an institution focusing on digital technologies, founded by entrepreneurs and academics active in the Costa Rican software industry, does have an institutional advisory board, which is extended with further members during new curriculum design, validation and review processes. Universidad Técnica Nacional (UTN), a public university, seeks input from employers during curriculum design, development and updating. Universidad Cenfotec interacted closely with industry advisors during the curriculum design and validation of their Bachelor of IT program, between 2006 and 2008.

Accreditation processes typically require universities to seek employers' views about the academic programs being assessed. In Peru, the Instituto de Calidad y Acreditación de Programas de Computación, Ingeniería y Tecnología (ICACIT) requires universities to establish an advisory board as a condition for accreditation. In Costa Rica, participation of employers in SINAES accreditation processes has been enthusiastic at some universities. As a result three universities have spawn advisory boards during the last four years. Chile accreditation processes 
take employers views in consideration, but do not require advisory boards to be established. Some Colombian universities have functioning advisory boards, though all those seeking ABET's accreditation will have advisory boards established as a result of their processes. Therefore, there is ample opportunity in Latin America to establish advisory boards across those universities who are planning to offer IT curricula aligned with the IT2017 curriculum guidelines.

\subsubsection{Experiential Learning}

Internships or Cooperative Education Opportunities are not a compulsory feature of computing-related programs in Latin American universities. Where they are implemented, they always involve employers. North America's cooperative education, in which students alternate work and study terms [79], is not common in Central or South America, although it is present at some Mexican universities. Typically, internships occur at the end of degree programs.

In some countries, admission to public universities is very competitive, and state-sponsored scholarships are scarce. Therefore students have to pay their way through university studies. For example, in Costa Rica, more than $60 \%$ of students pay for their university education and frequently have to get jobs in subjects different from their studies. For instance, they work during office hours and attend their classes during evenings and weekends. Some companies, both multi-nationals, such as Intel and Fiserv, and Costa Rican (e.g., Pernix, IntelligentSense, Akurey) have devised student-worker programs offering job positions for students to work on a part-time schedule (20 to 25 hours a week) while being required to continue their studies towards a bachelor degree in a computing discipline. Companies publish student-worker positions and reach university partners looking for suitable candidates. Some programs are targeted to young women, who receive special mentorship in addition to the student-worker arrangement. Some positions demand skills that students develop early in their studies. Approaches that articulate formal pathways between associate-level (2-year) and bachelorlevel (4-year) programs do exist and favor the start of a studentworker program following a practicum or internship that occurs at the end of the associate level of higher education; such programs exist in Information Technology and Software Engineering, with employers participating in curriculum design and validation [74].

Dual Education is a system that "combines apprenticeships in a company and vocational education at a vocational school in one course. In the company, the apprentice receives practical training which is supplemented by theoretical instruction in the vocational school" according to UNESCO [78]. Dual education is also known as "alternance" training". Cedefop [12] defines alternance training as: "Education or training combining periods in an educational institution or training center and in the workplace. An alternate scheme can take place on a weekly, monthly or yearly basis. Depending on the country and applicable status, participants may be contractually linked to the employer and/or receive a remuneration". This system has been a key strategy used by employers and governments in Europe (notably in Germany, Austria, Switzerland, Bosnia and Herzegovina, Croatia, Serbia, Slovenia, Macedonia, Montenegro, Denmark, the Netherlands and France) to prepare the young for entry into the workforce and thus combat unemployment of the young and help sustain productivity in industry [36]. Some Latin American universities in Colombia, Costa Rica, Ecuador, Guatemala, Mexico, and Peru have implemented "alternance" education for business and technical subjects, including computing. Some Latin American "enterprise universities" follow models inspired by Berufsakademie from the German state of Baden-Württemberg, a "higher education institution which combines on-the-job training and academic studies and, therefore, achieves a close integration of theory and practice, both being components of cooperative education" [31]. The International Labor Organization (ILO) and the German International Cooperation Agency are supporting the assimilation of this educational system in several Latin American countries $[19,30]$.

\subsubsection{Academia-Employer Forums}

Some countries are addressing the IT skills gap via the development of national or regional forums where representatives from academia, industry and (regional) government meet in order to address the challenges regarding the availability of an educated workforce on a timely basis: quantity, diversity of profiles, quality of their education, among others.

Mexico is promoting the development of Information and Communications Technology (ICT) clusters in several parts of the country, coordinated by the Consejo Nacional de Clústeres de Software y TICs (CANIETI) [70]. For example, the Cluster de Integradores de Alta Tecnología located in Guadalajara (Jalisco) groups professionals and companies implementing advanced ICT solutions, aiming at the creation of business networks, linking academia, government and industry [21]. InteQsoft's constituency, in Querétaro, comprises companies, universities and research centers developing technological solutions for industries such as Manufacturing, Trade, Services, Aircraft, Finance, and Automotive [5].

Costa Rica is a particular case. Computing-related graduates are in high demand there, surpassing the number of people graduating from universities, topping the profiles sought by recruiters $[9,18]$, with a gap exceeding 8,000 individuals in digital technologies [8] and nearly 5,000 in infrastructure IT [39]. There are two main factors that explain the gap: growth of the domestic market due to increased digitization of the economy, and the country's success in attracting foreign direct investment in IT services centers, due to initiatives promoted by the Costa Rican Investment Promotion Agency (CINDE) and the Ministry of Foreign Trade. Several multi-nationals operating in Costa Rica offer IT-related or ITenabled enterprise services worldwide. The services export sector has experienced a growth rate of $10.7 \%$ annually, and has generated over 56,000 jobs during a 12 -year period - half of which are related to digital technologies. CINDE, a group of multi-nationals and select universities meet several times a year to discuss the projected enterprise needs of ICT talent, as well as the training required for existing staff. Thus, universities understand the requirements for both academic, technical, and workplacerelated skills that should be developed in students. Universities receive sponsorship for curriculum development, companies offer paid training or postgraduate education to their employees, and areas of growth and opportunity are jointly identified. Cultivating these relationships has helped build trust between companies and universities, develop new or improved education or training programs, recruit adjunct faculty (or guest lecturers) from industry for advanced or postgraduate courses at universities, establish internship and student-worker programs, advance outreach programs, set forth social responsibility programs that involve company employees teaming with students and faculty, to name a few of the initiatives undertaken jointly by Costa Rican universities with both domestic and multinational companies. Such efforts have spawned a Web platform - The Talent Place for publicizing internships, certifications and training offered by 
employers to university students [16]. English is a foremost requirement for international business and technology work in IT [39]. Costa Rica launched in 2008 a national initiative, Tools for success, aimed at improving foreign-language mastery for international business and technical communications [28].

These relationships help universities gain insights into the trends in IT practice and world-class service management. When operating at a global scale, IT technological services, at their core, need to be offered in a consistent, high-quality manner, in the form of service-level agreements as part of out-sourcing services between companies or in-sourcing relationships within organizations. Collaborating with multinational companies helps Latin American universities understand the importance of quality in products and services offered at high standards and assured through organization-level processes, not only technology. Forums help transfer knowledge, practices and needs of multinational companies to universities via the expertise of their employees, who collaborate as panelists, members of advisory boards, adjunct faculty, student mentors and assessors, guest lecturers or sponsors, or peers in research projects, thus influencing the education of new generations of highly-skilled IT graduates from Latin American universities. Resulting professional practice will benefit private and public organizations operating in their domestic markets as well.

\subsubsection{Technology Vendors Collaborations}

Some computing technology vendors have a long tradition of collaborating with educational institutions via donations, generous discounts or licensing, comprising both software and hardware. Technology vendors that provide free software or heavily discounted licenses include: Apple, Bizagi, EMC, Facebook, Google, IBM, Intel, Microsoft, Oracle, PTC (ThingWorx), SAP, VMware, Yahoo. Some vendors donate or provide educational discounts in hardware: Cisco, Elastix (an Ecuadorian company), Furukawa Brazil, GBM, Hewlett-Packard, IBM, Intel, and Juniper. Others provide courseware (presentations, manuals, lab guides) and materials suitable for preparing candidates towards their certifications: Amazon, Elastix, EMC, Furukawa, Google, Hewlett-Packard, IBM, Intel, Juniper, Microsoft, Oracle, PTC (ThingWorx), SAP, VMware. With the advent of cloud technologies and services, some vendors provide free or low cost access to virtualized infrastructures suitable for lab work: Amazon, Cisco, EMC (NDG), Google, Hewlett-Packard, IBM, Intel, Juniper, Microsoft, Oracle, SAP, VMware. Other nontechnological multinationals, like Procter \& Gamble, sponsor challenges, hackathons and startup weekends, and provide resources to universities to facilitate student and faculty participations. In addition, some vendors have academic initiatives or alliances and allow universities to use their content and technology in academic program curriculum or continuing education settings, subject to constraints that vary for each provider.

\subsubsection{Continuing Education and Placement Programs}

Most Latin American countries have providers of continuing education services useful to industry. University-authorized training providers licensed by vendors, professional associations, and other actors participate in the continuing education market. In some countries, professional associations team with universities to provide continuing education to their professional constituencies.

Continuing education and postgraduate/specialty certificates (called Diplomado in several Latin American countries) offer universities the flexibility to develop and offer up-to-date training via short curricula that is pertinent for industry and their employees, yet not subject to the constraints of official approvals by national educational authorities.

Some universities offer in-house training or education to enterprises and government agencies, suited to their particular needs. Continuing education courses and specialty certificates have become the most flexible and responsive way of developing IT capabilities in Latin American countries, very frequently powered by virtual, on-line, education.

It is commonplace for Latin American universities to provide a placement program or office ('bolsa de empleo', 'bolsa de trabajo'). Employers can reach these offices for candidates. Many universities participate in organizing and promoting career fairs.

\subsubsection{Workforce and Curricular Recommendations}

Some Latin American countries have carried out projects that identify computing-related occupations available or needed by industry and government and map those occupations to curriculum recommendations for universities. One country that has seen workforce development as a strategic issue is Costa Rica. At national level, Costa Rica has conducted this kind of work with sponsorship from the ICT industry association (CAMTIC), the investment promotion agency (CINDE), domestic and multinational employers, and universities. For example, there have been studies of supply and demand ([17, 18, 47, 50]), qualitative analysis of the skill set gap ([9, 15, 48]), curriculum recommendations $([48,51])$, and strategy maps ([8, 48, 49, 59, 76]) that inform the development of the digital technologies and services industry in Costa Rica, serving both domestic and global markets.

\subsubsection{Entrepreneurship and Startup Incubation}

Technological startups and innovative entrepreneurship in ICT have existed in Latin America since the 1970s. Several universities and non-governmental organizations have put together courses, certificates, and mentoring programs that help entrepreneurs create, incubate, and accelerate their startups. Some national agencies make funds available to help companies grow and access international markets. Industry, governments, and universities collaborate in advisory boards on these initiatives or as company advisors. Universities are including innovation and entrepreneurship courses in their curricula [34]. Companies such as Cisco, Google, Microsoft and Telefónica sponsor hackathons, innovation, and entrepreneurship education, and seed and advise startups. Some companies, notably Telefónica (Movistar), have established an accelerator organization for digital startups, such as Wayra, which operates in several Latin American countries. Amazon, Google and Microsoft also help small businesses develop digital processes and commerce in their cloud environments, helping Costa Rican companies gain international customers via Web marketplaces. Those new ecosystems create opportunities for interdisciplinary work among advanced students or recent graduates from Software Engineering, Business Information Systems, Information Technology, Computer Science, Computer Engineering, and other non-ICT disciplines such as Business Administration, Industrial Engineering, Electronics and Communications Engineering, and Industrial and Product Design.

\subsection{Professional Practice}

Authors of the IT2008 Report [3] outline several potential mechanisms for incorporating material on professional practice into IT curricula. Some of these mechanisms are senior capstone 
courses, courses about professionalism, ethics, and laws, and practicum-internship-cooperation programs and team-based implementation courses. Additionally, there are other mechanisms at the highest institutional level such as consulting work, professional society and community service, summer fellowships, obtaining certifications and professional licensure, achieving accreditation, forming industrial advisory boards with appropriate charters, etc. In this section we will focus mainly on accreditations, internships (from the academia point of view), integrative courses (or projects), and courses about ethics.

\subsubsection{Accreditation}

Nowadays, market requirements in engineering and science point to "global" professionals able to perform without difficulties in different contexts and demonstrating authentic practices [14]. For these reasons, obtaining international accreditations becomes increasingly important for institutions of higher education to offer programs with international recognition. University programs in Latin America look for accreditations provided by different types of agencies, among them:

- National Agencies: CNA in Colombia, SINAES in Costa Rica, CEAACES in Ecuador, COPAES in México, CNA in Chile, SINEACE in Perú, and more.

- Regional initiatives: ARCU-SUR, CINDA, and RIACES, among others

- International agencies: ABET and CEAB.

Several studies explore accreditation initiatives in Latin America $[60,61,62,64]$. From the point of view of professional practice there are at least two advantages of having accredited programs. First, some accreditation systems like ABET [1] describe what students are expected to know and be able to do by the time of graduation, i.e., Student Outcomes (SO). Some SO are directly related to promote skills of professional practice (e.g., teamwork, lifelong learning, and knowledge of contemporary issues, among others). Additionally, some accreditation systems favor the relationship with industry, because they require the formation of industry representatives that offer advise on the curriculum.

Unfortunately, many universities in Latin American countries cannot have access to one accreditation model like ABET due to its costs. Other universities do not enter in such processes because they require a long time effort. There exists a wide diversity of accreditation models in Latin America [61]: mandatory, volunteers, competitive, private, and monopolist. Government regulations could affect the existence of some of these models. In some countries, for example, national accreditation is non-existent or volunteer for undergraduate programs (e.g. Venezuela and Colombia)

Accredited programs could attract more students because of their quality and the best opportunity to get a full time employment after graduation. Quality is ensured because accreditations must be renewed periodically, and this encourages the existence of a continuous improvement process within the program. Be recognized by an accrediting agency also ensures compliance with national and/or international standards.

\subsubsection{Internships}

With regards to the internships, there are many models in Latin American universities that vary by the number of credits (zero or more) and other factors such as the graduation requirement for internship completion within the study plan; evaluation methods of student learning; and the duration of the internship experience.
In some universities an internship can be used to replace the undergraduate final project, for example in the Computing Engineering program of Simón Bolivar University in Venezuela.

Tecnológico de Monterrey is a pioneer of mandatory internship, which was followed by other institutions. For instance, Tecnológico de Costa Rica (TEC) has mandatory practicums since founding its first three Engineering programs in 1973. TEC's first computing program, established in 1976, initially had two practicums (internships) at public or private organizations. The practicum occurs at the end of the fourth year of studies. While in practicum, TEC's computing students receive cosupervision from both a faculty member (who advises and assesses) and a professional from the hosting organization (who directs, mentors, and assesses). These internships have been a major differentiator for computing programs, for they are very successful in helping students hone their skills, learn to relate to persons and to organizations in real environments, and be more successful in obtaining job offers. Also in Costa Rica, Universidad Cenfotec includes internships at the end of the second year in all of its programs, one of which is the Bachelor in Information and Communications Technologies (BITIC), which aligns well with IT2008 [3]. At Cenfotec, internship processes are very well-structured, with roles of all participants (student, mentor-supervisor, advisor) clearly described; practicums finish with feedback assessments from hosting organizations to both the students and Cenfotec.

TEC and Cenfotec students earn academic credits for their practicums. These internships have fostered longtime collaborations with participating companies and educational institutions that have impacted curricula in various ways over time: validating skill sets, updating courses, improving teaching, including relevant subjects, and providing valuable input during curriculum revision and update processes. In some cases, the relationships thus constructed have led to in-kind donations of hardware and software for laboratory use, and workshops and research opportunities.

Student internships give industry experience with students and faculty. There is a big chance for industry to hire the interns when they graduate, which reduces costs in the hiring lifecycle process. With respect to mentoring activity, faculty can develop career growth and new skills that can be used as study cases in their courses. Non-mandatory practices in some Latin American computing-related programs can be seen as a weakness. On the other hand, administrative rules can hinder the implementation of internships abroad. The political and economic situations in some Latin American countries encourage students to request internships abroad. Another common problem is that academic mentor's work is not fairly recognized by the academy for faculty promotion. Finally, the duration of internships might not be sufficient for the industry.

\subsubsection{Integrative Projects}

Integrative courses or projects can be implemented in one or multiple semesters. When projects are carried out at the end of the degree, they are often called capstone projects. Students usually work in teams to design and implement projects. Projects may involve real-world issues including cost, safety, efficiency and suitability for the intended user [3]. The work may be developed solely for a particular course, but may also involve other on- or off-campus clients.

Lopez [45] defines an integrative project as an instructional strategy that involves making a set of articulated activities whose 
aim is to identify, interpret, argue, and solve a problem in an authentic context, and thus help develop a skillset that highly regarded by employers of IT graduates. Integrative projects usually consider addressing a significant problem in one or several of these contexts: research, social, professional, environmental, etc. Integrative projects must contemplate opportunities to learn to act holistically and not individually [81].

Parra [57] define Integrative Project (PI) for the Faculty of Engineering at Fundación Universitaria Panamericana Compensar (Colombia) as an educational strategy that integrates people, knowledge (theory and practice) areas, active learning methodologies, and interdisciplinary research, with the objective of generating solutions that contribute to social development through a university-enterprise relationship. In Fundación Universitaria Panamericana the integrative project starts in the first semester with an immersive process into the PI model, supported by specialized lectures and workshops for both students and teachers. The Program of Systems Engineering of the EAFIT University in Medellin (Colombia) also includes two integrative projects in its curriculum. The first project, in semester IV, aims to create a space where students apply, through collaborative work, the skills they have acquired throughout the first semesters. Students must face a real problem and propose a solution. In the second integrative project (semester VII), the objective is to strengthen the practical skills for solving problems of medium complexity to meet any need detected using ICT with an innovative approach. They must apply best practices in software development to ensure the quality of the solution according to four interrelated criteria that pertain to the people, project, product and processes involved.

Cenfotec from Costa Rica offers another example. Since their inception in September 2000, they offer curricula with a 'backbone' of three or four integrative projects. In these projects students learn to work collaboratively in teams with defined roles and processes, which vary according to project curriculum level. Students acquire new knowledge and combine it with previously acquired expertise in order to perform technical activities. They also learn to: a) work as teams using systematic engineering processes relevant to their digital technology sub-discipline; b) communicate effectively; c) be accountable as a team and individually (according to their role); d) research and apply diverse technologies; e) effectively manage individual and team work, and f) critically evaluate the artifacts of the development process $[73,75]$. The projects form a sequence of incremental 'stepping stones' distributed in the span of three years, in which students experience learn-by-doing and collaborative technological artifacts of increasing complexity, difficulty, diversity, heterogeneity, and realism, where non-technical workplace skills develop from the individual to the collective, each member growing in autonomy and responsibility. More experiences with integrative projects in institutions of higher education in Latin America Studies are described by [13, 58, 63].

Integrative projects encourage several useful skills for professional practice such as interdisciplinary and team work, effective communication, and solving real problems with constraints. This makes the projects highly recommended tools for achieving skills across curriculum. Industry participation may not exist in all implementations. Some higher education institutions have incorporated initiatives related to the development of integrative projects only within the framework of research processes or classroom activities [57]. University-industry relationship may be more suitable in a capstone project, since the students have greater knowledge to make a product more interesting and useful to the industry. Academia and industry can jointly conceptualize catalogues of needs suitable for developing capstone projects. As with internships, the development of a project with the industry can give teachers and students greater experience and visibility. Since students are exposed to industry practices and ethos, they have increased chances of employment when graduating.

In summary, implementing integrative or capstone project pose the following difficulties:

- Finding real problems that can be solved in one or two semesters (especially capstone projects) is challenging. For industry limited duration reduces the chances of having a finished project with high quality deliverables.

- People offering the projects have no time to mentor or supervise the students. It is also difficult to achieve $100 \%$ commitment of faculty guiding or accompanying the process.

- The number of credits may not reflect the time and effort spent by students and teachers.

- Non-technical workplace skills are difficult to teach and measure.

- An industry-sponsored capstone project that replaces the undergraduate final project may take away resources from other areas that usually take place towards the end of the academic experience, such as research or entrepreneurship.

\subsubsection{Ethics Courses}

The existence of other courses that encourage professional practice such as courses on ethics seems common and mandatory in some Latin American universities (e.g. Chile, Colombia, Peru and Costa Rica). Most of these courses, however, cover ethics in a general way. Garcia [33] explains the need of including ethical general principles, specific for computer science, in new curricula for teaching in IT-related programs. There is a constant emergence of new technologies that are changing our way of life, and very often those technologies are applied without any reflection on patterns of behavior that are consistent with human dignity. New terms have appeared, such as computer crime, software theft, hackers and viruses, etc., and they are part of our reality and represent major problems. Moreover, each of these problems creates ethical dilemmas for professional users of digital devices and online services, including social media.

We give two examples in Latin America where the issue of computer ethics is addressed. In the University of Managua (UNAM) the course of "Leadership and computer ethics" is integrated in the program of Systems Engineering [35]. In Costa Rica it is commonplace to have an ethics course in the engineering or technology programs. Some universities have ethics courses specific to computing. At Cenfotec, they cover general ethical principles and critical analyses, but always using computing for case studies and code of ethics developed by various computing-related professional, technical, and educational societies and organizations, such as ACM, IEEE, BCS, Software Engineering Code of Ethics and Professional Practice, System Administrators' Code of Ethics, as a frame of reference and discussion. Garcia [33] describes how to include general ethical principles, specific for computer science, in new curricula for teaching IT-related programs.

\subsection{Curricula Analysis}

In this section, we study the status of computing-related programs in Latin America. First, we present a brief review of programs 
related to computing. We then concentrate our interest on the curricula developed by some universities in the region as a way of comparison. This would develop a foundation and reference to the IT curriculum proposed in Section 5.

\subsubsection{Computing Program Names}

We conducted a web-based search of university programs related to computing in twenty Latin American countries: Argentina, Bolivia, Brazil, Chile, Colombia, Costa Rica, Cuba, Dominican Republic, Ecuador, El Salvador, Guatemala, Honduras, Mexico, Nicaragua, Panama, Paraguay, Peru, Puerto Rico, Uruguay, and Venezuela (Appendix A). In our search we used the following keywords: "Ingeniería" (Engineering), "Computación" (Computing), "Informática" (Informatics), "Sistemas" (Systems), "Tecnologías" (Technologies), "Información" (Information) and "Software". Additionally, we considered only university programs that require at least five years of study. A summary of our analysis findings includes the following:

- There exist 68 different names for programs related to computing;

- The most popular program names are "Ingeniería Informática" (Informatics Engineering) in 14 countries, "Ingeniería Telemática" (Telematics Engineering) in 11 countries, "Ingeniería de Sistemas" (Systems Engineering) in 10 countries, "Ingeniería en Computación" (Computer Engineering) in 9 countries, and "Ingeniería en Telecomunicaciones" (Telecommunications Engineering) in 9 countries;

- The term "Computación" (Computing) occurs 23 times in program names, 3 times for "Ingeniería de Computación" (Computer Engineering), 19 times for "Informática" (Informatics), 13 times for "Ingeniería de sistemas" (Systems Engineering), 10 times for "Ingeniería en Sistemas" (Engineering in Systems), 8 times for "Tecnologías de la Información" (Information Technologies), 5 times for "Ciencias de la Computación" (Computer Science), 5 times for "Ingeniería en Informática" (Informatics Engineering); times for "Ingeniería en Computación" (Engineering in Computing), and 2 times for "Ingeniería de Software" (Software Engineering);

- The term "Engineering" occurs in 58 program names;

- Some names are characteristic of specific countries, for instance, "Ingeniería Civil en Computación" (Civil Engineer in Computing)" is unique to Chile, "Ciencias en Computadoras" (Science in Computers) in Cuba, "Ingeniería de Sistemas en Computación" (Systems Engineering in Computing) in Guatemala, and "Ingeniería de Computación y Sistemas" (Computer and Systems Engineering) in Peru;

- Some program names look redundant, for instance "Computación e Informática" (Computing and Informatics) and "Ingeniería de Sistemas, Informática y Ciencias de la Computación" (Systems Engineering, Informatics and Computer Science), both occurring in Guatemala.

It is well known that a program name is not always consistent with the curriculum content [40]. In fact, the selection of a program name is usually influenced by a market strategy (e.g. an "Engineering" degree gives some kind of social status in most Latin American countries [68]). In spite of this, it is possible to identify some commonalities among computing-related programs in Latin America: very attractive for high school students; strong education on fundamental science (mathematics and physics); recognized as challenging and time-demanding; and high employment rate.

\subsubsection{Representative Curricula}

In the following, we concentrate our study on fourteen undergraduate programs and ten postgraduate (or master) programs related to IT in Latin America (Tables 3.1 and 3.2). The selected programs matched the terms "Information", "technology", "systems" and "informatics". Additionally, the programs were further examined based on the names of their courses. We determined that the selected programs have a deep knowledge on basic sciences (e.g., math, physics) and computer science (e.g., programming, networking).

Table 3.1 IT-related undergraduate programs in Latin America

\begin{tabular}{|c|c|c|}
\hline Number / Title & University & $\begin{array}{c}\text { Only } \\
\text { II }\end{array}$ \\
\hline $\begin{array}{l}\text { Systems Engineer } \\
\text { (ingeniero de sistemas) }\end{array}$ & $\begin{array}{l}\text { Universidad Tecnológica Boliviana } \\
\text { (Bolivia) } \\
\text { Universidad San Francisco de Quito } \\
\text { (Ecuador) } \\
\text { Universidad de los Andes } \\
\text { (Venezuela) }\end{array}$ & No \\
\hline $\begin{array}{l}\text { Systems and Informatics } \\
\text { Engineer (ingeniero de sistemas e } \\
\text { informática) }\end{array}$ & $\begin{array}{l}\text { Universidad Alas Peruanas (Perú) } \\
\text { Universidad de Bogotá Jorge Tadeo } \\
\text { Lozano (Colombia) }\end{array}$ & No \\
\hline $\begin{array}{l}\text { Information Systems Engineer } \\
\text { (ingeniero en sistemas de } \\
\text { información) }\end{array}$ & $\begin{array}{l}\text { Universidad Andina del Cusco (Perú) } \\
\text { Universidad Tecnológica Nacional } \\
\text { (Argentina) }\end{array}$ & No \\
\hline $\begin{array}{l}\text { Business Informatics Engineer } \\
\text { (ingeniero en informática } \\
\text { empresarial) }\end{array}$ & Universidad de Talca (Chile) & No \\
\hline $\begin{array}{l}\text { Information and Management } \\
\text { Control Engineer (ingeniero de } \\
\text { información y control de gestión) }\end{array}$ & \begin{tabular}{|l} 
Universidad Austral de Chile (Chile) \\
\end{tabular} & No \\
\hline $\begin{array}{l}\text { Information and Comm. } \\
\text { Technology Engineer } \\
\text { (ingeniero de tecnologías de la } \\
\text { información y comunicación) }\end{array}$ & $\begin{array}{l}\text { Universidad Iberoamericana } \\
\text { (Dominican Republic) }\end{array}$ & Yes \\
\hline $\begin{array}{l}\text { Licentiate in Information } \\
\text { Technology (licenciado en } \\
\text { tecnologias de la información) }\end{array}$ & $\begin{array}{l}\text { Universidad de Palermo (Argentina) } \\
\text { Universidad Autónoma de Nuevo } \\
\text { León (México) } \\
\text { Universidad de Insurgentes (México) }\end{array}$ & Yes \\
\hline $\begin{array}{l}\text { Information Technology and } \\
\text { Systems Engineer (ingeniero de } \\
\text { Tecnologías de la Información y } \\
\text { Sistemas) }\end{array}$ & $\begin{array}{l}\text { Universidad ESAN (Peru) } \\
\text { Universidad Cenfotec (Costa Rica) }\end{array}$ & Yes \\
\hline $\begin{array}{l}\text { Information Technology } \\
\text { Engineer (ingeniero en } \\
\text { Tecnologias de la Información) }\end{array}$ & $\begin{array}{l}\text { Universidad Técnica Nacional (Costa } \\
\text { Rica) }\end{array}$ & Yes \\
\hline $\begin{array}{l}\text { Licentiate in Development of } \\
\text { Information Technologies } \\
\text { (licenciado en desarrollo de } \\
\text { tecnologias de la información) }\end{array}$ & Universidad UVM (México) & Yes \\
\hline $\begin{array}{l}\text { Licentiate in Information } \\
\text { Technology Engineering } \\
\text { (licenciado en ingeniería en } \\
\text { Tecnologías de la Información) }\end{array}$ & $\begin{array}{l}\text { Benemérita Universidad Autónoma } \\
\text { de Puebla (México), }\end{array}$ & Yes \\
\hline $\begin{array}{l}\text { Computer and Systems } \\
\text { Engineering }\end{array}$ & Universidad de los Andes (Colombia) & No \\
\hline Informatics Engineer & Universidad Católica de Uruguay & No \\
\hline Computer Science & Universidad Sao Paulo (Brazil) & No \\
\hline
\end{tabular}

In Latin America, we can find a considerable number of programs that contain several IT domains: some of them have been identified in the IT2017 report, while others originate from domains specific to other computing disciplines. Therefore, ITrelated programs have different names, such as systems and informatics or information and control management, which creates certain confusion among students and industry stakeholders. The reason behind the many names of IT-related programs might stem from not knowing what an IT program exactly means. In the IT-related programs currently offered in Latin America, it is possible to find many courses on the 
fundamentals of computer science (e.g., programming, data structures, analysis of algorithms), which limits the choice for courses in IT domains that the IT2017 report identifies as essential (e.g., cyber-security, user experience design).

Written and oral communication skills are not cultivated in ITrelated programs; indeed, engineering programs do not usually prepare students for this kind of skills. In addition, Latin America pre-university education does not commonly include English courses; students entering university studies are not proficient in English. Current IT-related programs do not include enough English courses to address this gap.

There exist a considerable number of postgraduate programs (certificates, diplomas, master's degrees) and certification courses in Information Technology, some of which are combined with other programs such as management and business. This indicates an interest in IT Management in Latin America and points to a need for professionals in IT. Moreover, government regulations do not impose courses that do not relate to the program's disciplinary content like religion and political science.

Table 3.2 IT-related graduate programs in Latin America

\begin{tabular}{|c|c|c|}
\hline Number / Title & University & $\begin{array}{c}\text { Only } \\
\text { II }\end{array}$ \\
\hline $\begin{array}{l}\text { Master en Gestión de Tecnología } \\
\text { de Información }\end{array}$ & $\begin{array}{l}\text { Universidad Nacional Abierta } \\
\text { y a Distancia (Colombia) }\end{array}$ & Yes \\
\hline $\begin{array}{l}\text { Master en gerencia en tecnologías } \\
\text { de la información }\end{array}$ & $\begin{array}{l}\text { Universidad Santa María - } \\
\text { Sede Posgrado (Venezuela) }\end{array}$ & Yes \\
\hline $\begin{array}{l}\text { Master en Gestión Estratégica de } \\
\text { Tecnologías de la Información }\end{array}$ & $\begin{array}{l}\text { Universidad de Cuenca } \\
\text { (Ecuador) }\end{array}$ & Yes \\
\hline $\begin{array}{l}\text { Magíster en Dirección Estratégica } \\
\text { en Tecnologías de la Información }\end{array}$ & $\begin{array}{l}\text { Universidad Internacional Tres } \\
\text { Fronteras (Paraguay) }\end{array}$ & Yes \\
\hline $\begin{array}{l}\text { Maestría en Administración de } \\
\text { Tecnologías de Información }\end{array}$ & $\begin{array}{l}\text { Tecnológico de Monterrey } \\
\text { (México) } \\
\text { Universidad Nacional (Costa } \\
\text { Rica) }\end{array}$ & Yes \\
\hline $\begin{array}{l}\text { Maestría en Tecnologías de } \\
\text { Información y Administración }\end{array}$ & Universidad ITAM [México] & Yes \\
\hline $\begin{array}{l}\text { Maestría de las Tecnologías de la } \\
\text { Información }\end{array}$ & $\begin{array}{l}\text { Universidad de Guadalajara } \\
\text { (México) }\end{array}$ & Yes \\
\hline $\begin{array}{l}\text { Maestría en Tecnología de } \\
\text { Información }\end{array}$ & $\begin{array}{l}\begin{array}{l}\text { Universidad de Palermo } \\
\text { (Argentina) }\end{array} \\
\end{array}$ & Yes \\
\hline $\begin{array}{l}\text { Governança em Tecnologia da } \\
\text { Informação }\end{array}$ & $\begin{array}{l}\text { Centro Universitário de } \\
\text { Brasília (Brazil) }\end{array}$ & Yes \\
\hline $\begin{array}{l}\text { Maestría en Administración de } \\
\text { Recursos Informáticos }\end{array}$ & $\begin{array}{l}\text { Universidad Latina (Costa } \\
\text { Rica) }\end{array}$ & Yes \\
\hline
\end{tabular}

Many of the obstacles to curriculum development relate to Latin American governments' decisions. For example, Chile's government requires a fixed number of five years for engineering programs. In Venezuela the names of programs are regulated by government. Political, economic, and social instability in Latin American countries can affect the creation, development and evolution of IT-related programs. For instance, due to the economic crisis in Venezuela, its government has not increased public universities' budgets according to their growing needs, making it impossible to pay professor salaries and renew infrastructure.

\section{FACULTY AND EMPLOYER FEEDBACK}

As technology has evolved and taken on greater importance within society, industry has come to rely on IT to be a catalyst spurring continued growth. In focusing on Latin America, we were able to explore and understand the relationship between academia and industry and those factors that are key to understanding this relationship such as cultural, geographic, political, industry and other considerations. Increasingly, it is critical that academia forge a partnership with employers of IT graduates to be able to create technology-oriented graduates who are able to fill expanding demands. This relationship is essential to create modern and relevant IT curriculum that includes technical, intrapersonal, and interpersonal skills [NRC2012] as required by a society requiring specific IT needs.

To gain insights into which IT skill sets mean to academia and employers, the authors designed two online surveys, one for IT professionals and one for IT faculty members. With support from ACM, the surveys were administered in the summer of 2016.

\subsection{Data Collection}

Three members of the IT2017 Executive Committee and a statistician designed two surveys for computing faculty and employers in Latin America (Appendix B). The purpose of the surveys was to gain insights into professional competencies IT graduates should have; and how to improve academia-employer collaborations. The surveys were bilingual: English and Spanish for Spanish-speaking countries in Latin America, and English and Portuguese for distribution in Brazil. The surveys were hosted on the Survey Monkey platform and distributed in June 2016. Survey responses were given routine data cleaning to eliminate spurious responses and recode "other" responses into admissible answers when possible.

Latin American members of the working group distributed both surveys via email in their countries, by reaching out to a wide range of organizations: academic departments, educational and professional organizations, and IT professionals. The number of organization data sources by country and type are shown Table 4.1 The working group reached out to these organizations with the purpose to understand how and why undergraduate IT programs and employers were working together and to ascertain their expectations.

Table 4.1 Organization data sources by country and type.

\begin{tabular}{|c|c|c|c|c|c|}
\hline Country & \multicolumn{2}{|c|}{ Academia } & Industry Government & $\begin{array}{c}\text { Professional } \\
\text { Organizations }\end{array}$ & $\begin{array}{c}\text { Total } \\
\text { contacts }\end{array}$ \\
\hline Argentina & & 1 & & & 1 \\
\hline Chile & 14 & & & 1 & 15 \\
\hline Colombia & 12 & 8 & 3 & 3 & 26 \\
\hline Costa Rica & 13 & 3 & & 5 & 21 \\
\hline Peru & 3 & 3 & 2 & 4 & 12 \\
\hline Venezuela & 4 & & & & 4 \\
\hline Total & $\mathbf{4 7}$ & $\mathbf{1 5}$ & $\mathbf{5}$ & $\mathbf{1 3}$ & $\mathbf{8 0}$ \\
\hline
\end{tabular}

IT professionals from Latin America were recruited from a variety of organizations that serve the IT industry sector, such as the Project Management Association (PMI) in Costa Rica, the IEEE Computer Society Chapter in Costa Rica, the ICT Technical Chamber in Chile, (part of the Chilean government), the Banco de la República in Colombia, the APESOFT Asociación Peruana de Software y Tecnologías, a Peruvian trade association, and IT Application Consulting (ITAC) in Columbia. In total, the working group reached out to fifteen employers and five government agencies. Faculty members in computing departments in Latin America were similarly recruited from a wide variety of 46 academic institutions and thirteen professional organizations. Some of the universities that were polled for survey recruitment included Universidad Nacional Autonome de Costa Rica, Universidad de Concepcion in Chile, the Universidad Catolica de Columbia, Universidad Simon Bolivar in Venezuela and the Universidad La Salle in Peru. 


\subsection{Survey Design and Participation}

The survey questions collected institutional information and feedback on workplace skills [56], and academia-employer collaborations. The faculty survey asked eight questions (Appendix B1). A total of 182 faculty members responded. The employer survey asked ten questions (Appendix B2). A total of 182 computing faculty members and 177 employee representatives responded. In both surveys the questions were a mix of multiple-choice and free form responses.

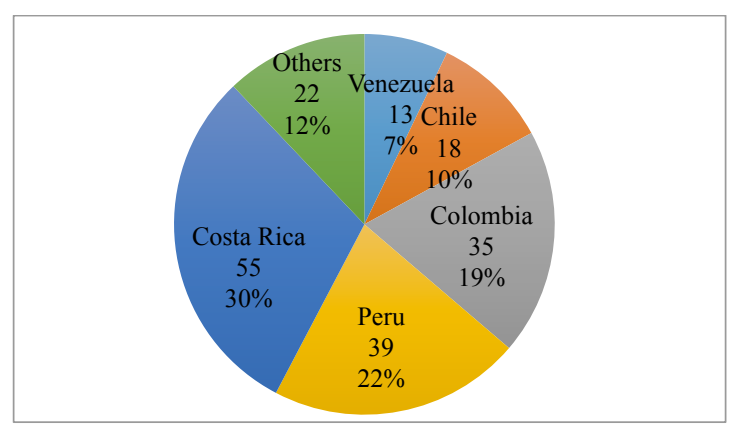

Figure 4.1 Faculty participation by country.

Six questions are common to both surveys: two questions pertain to demographics: country of the respondent's academic institution or organization and respondent's gender (survey items F1/E1 and F2/E3, Appendix B). Four questions seek feedback about desirable workplace skill set of IT graduates (F6/E7) and ways to develop and maintain effective collaborations between academia and employers (F7/E9 and F8/E10).

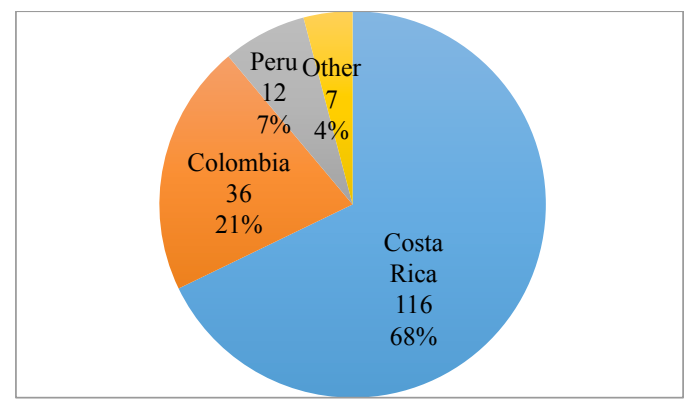

Figure 4.2 Employer participation by country.

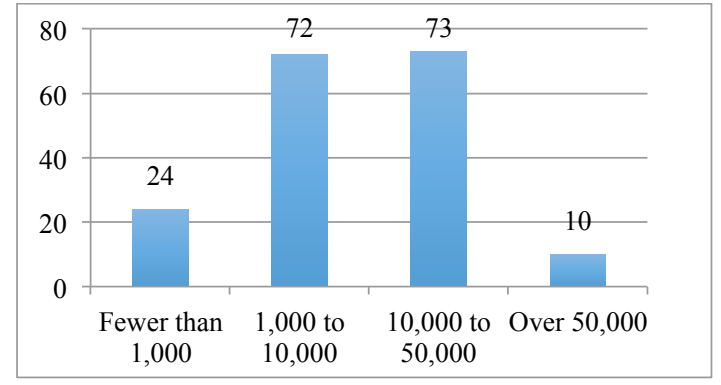

Figure 4.3 Size of computing departments (total student enrollment) of survey respondents.

A total of 178 computing faculty from 15 countries indicated their country of origin and a total of 178 employer survey responses indicated four countries and five multinational locations (Figures 4.1 and 4.2). Highest participation from both surveys was from Costa Rica, Colombia, and Peru.
Figures 4.3 and 4.4 show the distribution of sizes of academic institutions and organizations in which respondents' work: student enrollments (Figure 4.3) and full-time employee totals (Figure 4.4).

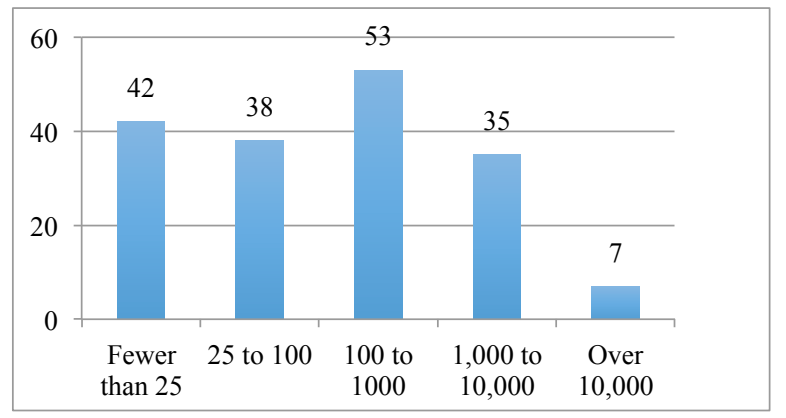

Figure 4.4 Size of employer organizations (total full-time employees) of survey respondents.

A closer look at the respondents' affiliations shows that faculty represented computing departments of all sizes, with a fairly uniform distribution of student enrollments (Figure 4.5).

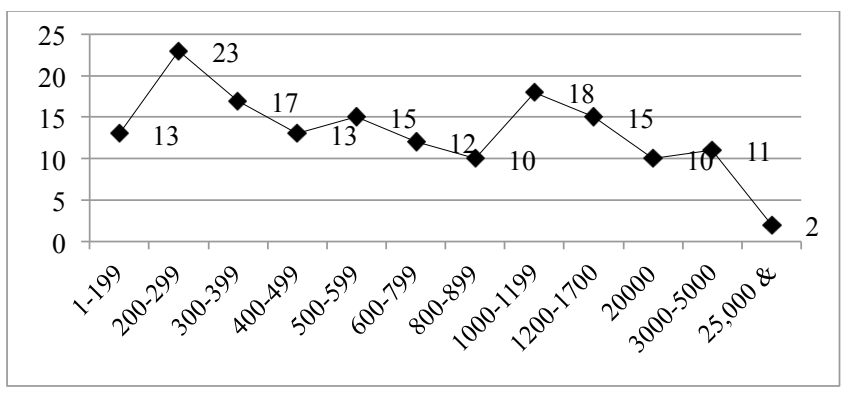

Figure 4.5 Student enrollment in academic departments (all computing programs) of faculty respondents.

Close to half of employer survey respondents indicated other titles than the five prompted answers: CIO, CTO, Senior VicePresident, Senior Director, and IT Manager/Director (77/175, $44 \%$ ). Among the reported titles, IT manager represented $27 \%$, compared to $29 \%$ of all responses representing the remaining four prompted titles. Gender representation was almost identical in the two groups: $23 \%$ faculty females and $22 \%$ employer females. The gender gap among survey respondents matches the Deloitte Global's prediction [44] that by "end of 2016 fewer than 25 percent of IT jobs in developed countries will be held by women."

\subsection{Discussion of Results}

\subsubsection{Non-technical Workplace Skills}

Both groups were asked "... what non-technical workplace skills are considered the most important" for IT students or employees to have upon graduation or when they join the employer organization (Appendix B1, F6; Appendix B2, E7). Both surveys listed the same prompted options, including a free-text for "Other (please specify)" option (Appendix B3). 174 faculty and 170 employers responded to the question.

Table 4.2 shows the response prompts, along with counts and percentages of respondents who voted for each item. Skill preferences are ordered by employer rank among the 13 items (from highest to lowest). It is reassuring to see how closely aligned the two groups are. The top eight non-technical workplace skills had identical rankings for both groups with the exception of the answers ranked $2^{\text {nd }}$ and $3^{\text {rd }}$, which were swapped. 
Table 4.2 Employer and faculty choices of workplace skills IT students should have upon graduation. Workplace skill preferences are ordered by employer rank among the 13 items (from highest to lowest).

\begin{tabular}{|c|c|c|c|c|c|c|}
\hline & \multicolumn{3}{|c|}{$\begin{array}{c}\text { Employer } \\
\text { survey }\end{array}$} & \multicolumn{3}{c|}{$\begin{array}{c}\text { Faculty } \\
\text { Survey }\end{array}$} \\
\hline Prompted options & Votes & $\%$ & Rank & Rank & $\%$ & Votes \\
\hline Working in teams & 145 & $85 \%$ & 1 & 1 & $84 \%$ & 146 \\
\hline $\begin{array}{c}\text { Analyzing and solving complex } \\
\text { problems }\end{array}$ & 131 & $77 \%$ & 2 & 3 & $76 \%$ & 133 \\
\hline Critical and analytical thinking & 119 & $70 \%$ & 3 & 2 & $78 \%$ & 135 \\
\hline Communication (spoken and written) & 117 & $69 \%$ & 4 & 4 & $63 \%$ & 110 \\
\hline Planning and organizational & 98 & $58 \%$ & 5 & 5 & $57 \%$ & 99 \\
\hline $\begin{array}{c}\text { Collaborating with people from } \\
\text { different backgrounds }\end{array}$ & 92 & $54 \%$ & 6 & 6 & $46 \%$ & 80 \\
\hline $\begin{array}{c}\text { Proficiency in more than one } \\
\text { language }\end{array}$ & 65 & $38 \%$ & 7 & 7 & $45 \%$ & 78 \\
\hline Ethical reasoning & 61 & $36 \%$ & 8 & 8 & $43 \%$ & 75 \\
\hline Negotiation & 53 & $31 \%$ & 9 & 11 & $25 \%$ & 43 \\
\hline Empathy and sensitivity to others & 43 & $25 \%$ & 10 & 9 & $26 \%$ & 46 \\
\hline Professional networking & 19 & $11 \%$ & 11 & 10 & $26 \%$ & 45 \\
\hline Other (please specify) & 9 & $5 \%$ & 12 & 13 & $8 \%$ & 14 \\
\hline Self-reflection & 8 & $5 \%$ & 13 & 12 & $16 \%$ & 27 \\
\hline
\end{tabular}

\subsubsection{Employer-Academia Collaborations}

Three questions common to both surveys focused on employeracademia collaborations. Both groups were asked whether they collaborate or partner with each other in efforts to make academic IT programs more responsive to workplace needs (F5/E6, Appendix B1/B2). 178 faculty and 174 employers responded to this question and indicated contrasting situations.

Table 4.3 Employer and faculty choices of ways to collaborate to improve student workplace-relevant skills (technical and nontechnical). Collaboration choices are ordered by employer rank among the nine items (from highest to lowest).

\begin{tabular}{|c|c|c|c|c|c|c|}
\hline & \multicolumn{3}{|c|}{$\begin{array}{c}\text { Employer } \\
\text { survey }\end{array}$} & \multicolumn{3}{c|}{$\begin{array}{c}\text { Faculty } \\
\text { Survey }\end{array}$} \\
\hline Prompted options & Votes & $\%$ & Rank & Rank & $\%$ & Votes \\
\hline Internships & 128 & 76 & 1 & 1 & $85 \%$ & 144 \\
\hline Part-time jobs & 77 & $46 \%$ & 2 & 3 & $54 \%$ & 92 \\
\hline IT course teaching experts & 70 & $41 \%$ & 3 & 2 & $62 \%$ & 105 \\
\hline Student advising/mentoring & 67 & $40 \%$ & 4 & 6 & $47 \%$ & 80 \\
\hline Full-time jobs & 59 & $35 \%$ & 5 & 8 & $23 \%$ & 39 \\
\hline Advisory board services & 58 & $34 \%$ & 6 & 5 & $48 \%$ & 81 \\
\hline Workforce skills teaching experts & 57 & $34 \%$ & 7 & 3 & $54 \%$ & 92 \\
\hline Curriculum development expertise & 49 & $29 \%$ & 8 & 7 & $38 \%$ & 64 \\
\hline Other (please specify) & 5 & $3 \%$ & 9 & 9 & $5 \%$ & 9 \\
\hline
\end{tabular}

Both groups were asked to indicate the ways in which their organizations are most likely to collaborate to improve students' workplace-relevant skills (technical and non-technical). The survey question (F7/E9, Appendix B1/B2) did not restrict the number of choices: "Choose all that apply." Table 4.3 shows the response prompts, along with counts and percentages of respondents voting for each item, and rank among the nine items.

Over two thirds of faculty attested to the existence of collaborations and partnerships with employers (136/178, 76\%), while the majority of employers indicated the opposite $(101 / 74$, $58 \%$ ). The same number of 169 respondents chose from the list of nine item options, including "Other", for each survey. Faculty, however, cast more votes (706, 4.2 per respondent) than employers (570 votes, 3.4 per respondent).

The two groups' responses showed reasonable agreement about the ways in which academia and employers could collaborate. Employer and faculty agreed on the top three ways of collaboration: internships, part-time jobs, and having employers provide experts to teach IT courses. Another remarkable result is that faculty showed stronger support (votes and percentages) for all items except for one: "Full-time jobs" received 59 votes $(35 \%)$ from employers and 39 votes $(23 \%)$ from faculty. Despite this difference, it is remarkable that both groups ranked this choice of collaboration very high: rank \#2 for faculty and rank \#3 for employers (Table 4.3).

Figure 4.6 compares the percentages of respondents voting for each item in both groups. Two ways of collaboration showed the largest percentage difference between faculty and employers: faculty seeking and employers providing IT course teaching experts; and faculty seeking and employers providing workforcerelevant skills non-academic settings.

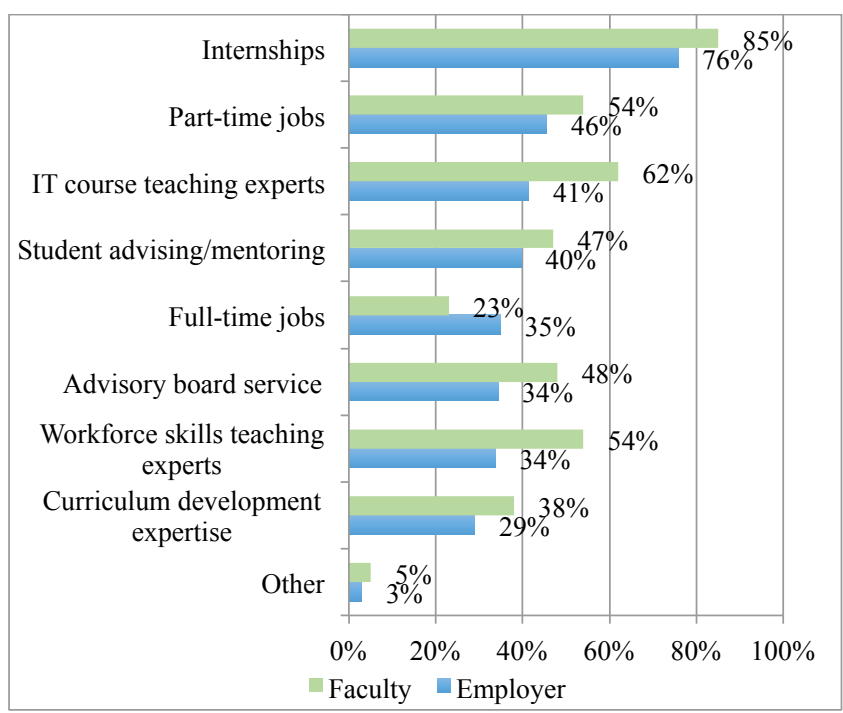

Figure 4.6 Comparison between faculty and employer choices for ways to collaborate to improve students' workplace-relevant skills (technical and non-technical), based on percentages of respondents who voted for each item. Collaboration choices are ordered by employer rank among the nine items (from highest to lowest).

The highest disagreement measured as difference in rankings for the prompted ways of collaboration was for the items "Seeking/providing workforce skills teaching experts in nonacademic settings" and "Getting access to/offering full-time jobs for students" (Figure 4.7). Faculty ranked the item "Seek workforce skills teaching experts ...”\#3, while, employer's rank was \#7. Faculty and employer showed comparably different support for offering students full-time jobs: employer's rank was \#5 and faculty's rank was \#8. 


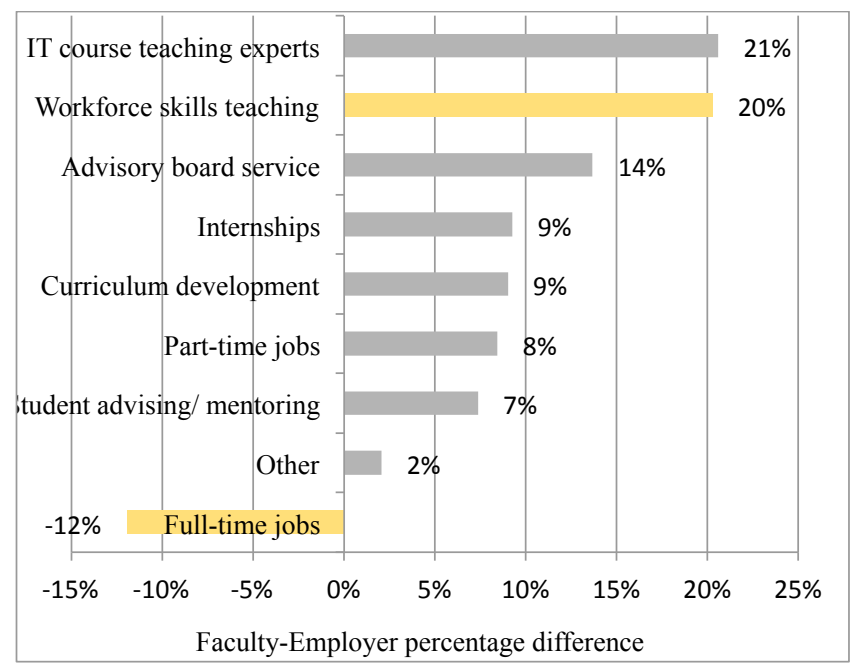

Figure 4.7 Faculty-employer difference of percentages of respondents voting for each of the nine items describing ways of collaboration.

Faculty and employer groups were asked about what motivates their organization to develop and sustain collaborations with each other. The survey question (F8/E10, Appendix B1/B2) did not restrict the number of choices.

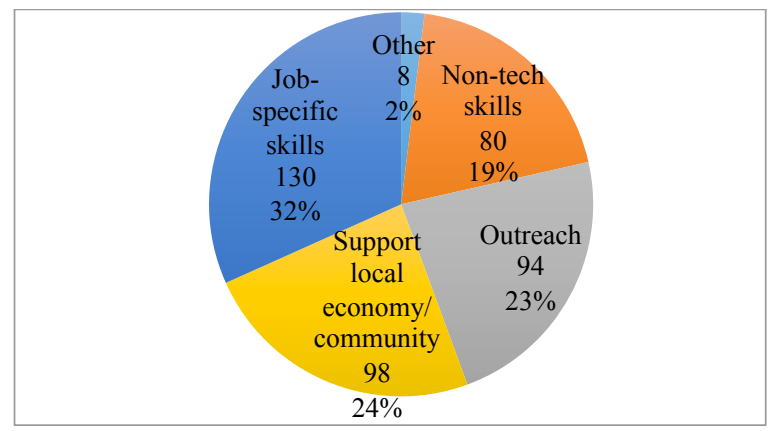

Figure 4.8 Faculty preferences for what motivates academia-employer collaborations.

169 faculty and 167 employers chose from the list of five item options (including "Other"). Faculty cast slightly more votes (410 votes, 2.5 votes/response) than employers (365, 2.2 votes/response).

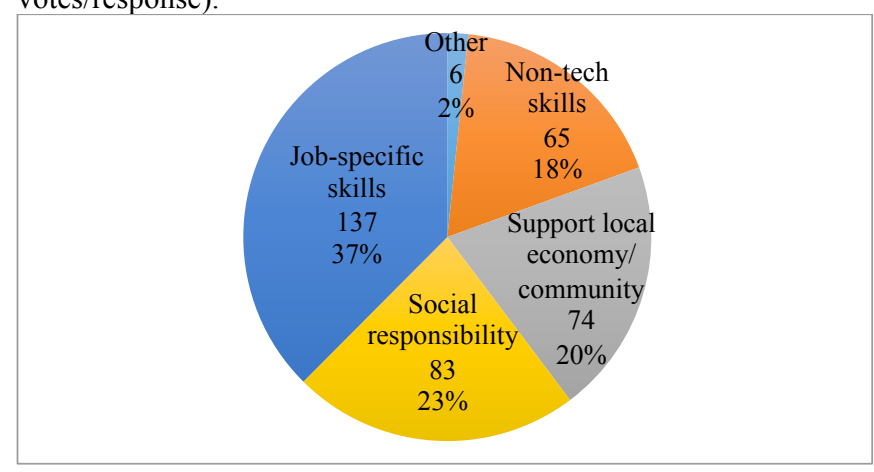

Figures 4.8 and 4.9 show the counts and percentages of respondents voting for each item. Preferences for what motivates academia-employer collaborations show very similar agreement, with job-specific skills meeting the most sought need for developing and sustaining impactful collaborations.

\subsection{IT2017 Face-to-Face Poster Presentation Poll}

Throughout the five days of face-to-face meetings, the working group engaged in many discussions and debates on gathering information and interpreting results. The interaction proved helpful in fleshing out details and bringing closure to many general and specific opinions in proposing a futuristic information technology curriculum for Latin America.

During the July 2016 ITISCE conference, and in order to draw attention to the importance of academic-workplace collaborations, a poster on Industry perspectives and the IT2017 Report was created and presented. Highlighted were some of the key findings of the industry survey, performed in the summer of 2015 for the IT2017 report. In conjunction with this poster presentation, we also distributed a short two question survey, polling participants of the conference to determine if they have any formal collaborations with industry sector or government agencies; i.e., such as internships, co-op programs, advisory boards, full-time or part-time job placement).

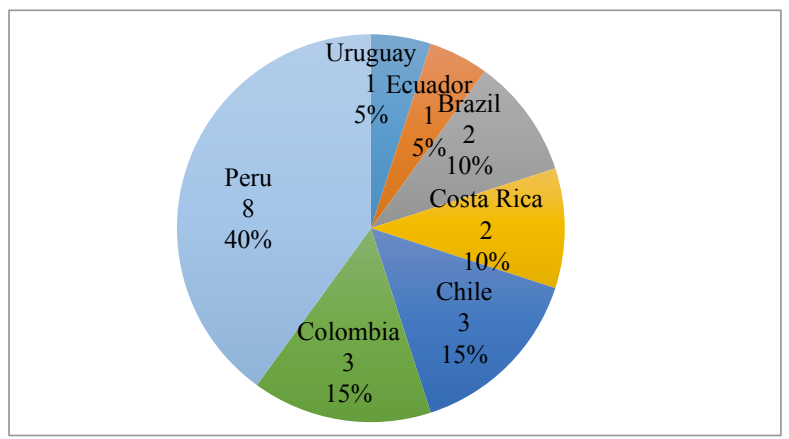

Figure 4.10 Face-to-face poster presentation survey participants by Latin American country

The conference audience consisted of attendees from 37 countries and reflected a global perspective of IT, to help us gain more insight into academia/employer partnerships. For the purpose of this paper, we are going to limit our attention to participants from Latin America, who consisted of attendees from seven countries, including Brazil, Chile, Columbia, Costa Rica, Ecuador, Peru and Uruguay.

In addition to polling for affiliation information, participants were asked about the forms of collaborations that their universities have with government and industry employers. The question listed the same nine response prompts as questions F7/E9, Appendix B1/B2.

There were 165 total attendees at the ITISCE 2016 conference, 30 of which came from Latin America. Out of 30 attendees, 20 persons filled out the poster survey (67\% response rate). Highest participation from our survey was from Peru, followed by Chile and Columbia (Figure 4.10).

Figure 4.9 Employer preferences for what motivates academia-employer collaborations. 


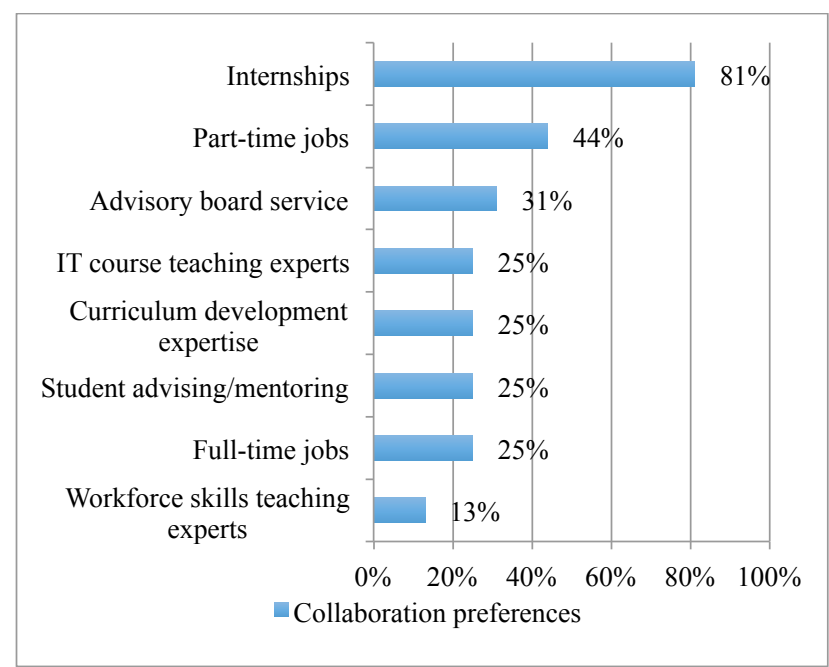

Figure 4.11 Faculty choices on the ITiCSE 2016 poster survey for ways in which their universities collaborate with government/industry employers, based on percentages of respondents who voted for each item. Collaboration choices are ordered by employer rank among the eight items (from highest to lowest).

In response to the question on types of collaborations, the most popular type of collaboration were internships ( $81 \%)$, followed by part-time jobs (44\%), and recruiting for advisory boards $(31 \%)$. $25 \%$ of poster survey respondents indicated that they also worked with employers to seek and benefit from their expertise in teaching IT courses and workforce skills (Figure 4.11).

\section{PROPOSAL OF AN IT PROGRAM FOR LATIN AMERICA}

This section proposes a futuristic IT program for Latin American. Our proposed curricular model was elaborated by taking into account the Strengths, Weaknesses, Opportunities, and Threats (SWOT) analysis findings and survey results and discussion presented in Sections 3 and 4. As Table 5.1 shows, the proposed program of study contains six required computer science (CS) courses ( 22 credits) and 22 required information technology (IT) courses (62 credits).

To design this program, we have been inspired by the proposed program presented in the IT2017 report (version 0.61). The proposed program offers flexibility with its three IT elective courses ( 9 credits). These electives can be selected to cover the supplemental IT2017 domains according to the goals of the program. In addition, the capstone experience occurs over two courses in the last year, allowing for a substantial and complete practical experience. Students are required to join an IT center full time for at least 8 weeks to complete 280 hours to pass the practical training course. Based on particular features of Latin American countries and new trends in information technologies this proposal identifies distinguishing variations.

\subsection{Use of English}

Although Latin-America countries have been influenced by the United States' culture, the use of English language is not commonly strong among students of these countries (Section 3). However, this language is fundamental in IT degree programs since most technical literature, online courses and videos, and other online IT resources are only available in English. English language continues to be the language of international business.
To address these issues, our proposal includes four English courses and requires that students obtain an international English certification at the end of the fourth semester. As expressed by employers providing IT services internationally from Latin American countries, English mastery certification should aim at the B2 level of English, according to the Common European Framework of Reference for Languages [26].

Table 5.1 Composition of courses of the proposed IT program

\begin{tabular}{|c|c|c|}
\hline $\begin{array}{c}\text { Requirement } \\
\text { Type }\end{array}$ & $\begin{array}{l}\text { No. of } \\
\text { Courses! } \\
\end{array}$ & $\begin{array}{l}\text { 'Credit } \\
\text { 'Hours }\end{array}$ \\
\hline $\begin{array}{l}\text { University } \\
\text { Requirements }\end{array}$ & 8 & 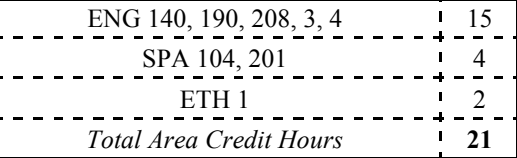 \\
\hline $\begin{array}{l}\text { Department } \\
\text { Requirements } \\
\text { (General) }\end{array}$ & 5 & $\begin{array}{rr}\text { COM 207, } 3 & 1 \\
\\
-1\end{array}$ \\
\hline $\begin{array}{c}\text { Department } \\
\text { Requirements } \\
\text { (Math \& Science) }\end{array}$ & 5 & 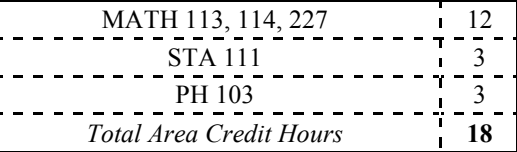 \\
\hline $\begin{array}{l}\text { Department } \\
\text { Requirements } \\
\text { (Filed } \\
\text { Specific) }\end{array}$ & 28 & \begin{tabular}{c:c}
$\mathrm{CS}_{\mathrm{A}} 104,106,220$ & 10 \\
\hdashline $\mathrm{CT}_{\mathrm{A}} 280,300,301,310,315,320,331$, & 34 \\
\hdashline $\mathrm{IT}_{\mathrm{A}} 410,412,420,490,491,492,493$, & 31 \\
\hdashline$-800,6,7,900,8$ & 12 \\
\hdashline $\mathrm{IT}$ Electives Courses & \\
\hdashline Total Area Credit Hours & $\mathbf{9 6}$
\end{tabular} \\
\hline $\begin{array}{c}\text { Total Credit } \\
\text { Hours }\end{array}$ & 46 & Total Credit Hours \\
\hline
\end{tabular}

\subsection{Duration of Programs}

Due to government regulations on the duration of undergraduate programs (e.g. five years in Chile and Peru, four years in other countries), the proposed curricular model was designed for four years. Although for this proposal we follow the four-year curricular framework of the IT2017 report, we suggest adding a "zero" year, which contains necessary courses to level up the standard to international levels. IT-related programs in Latin America have a strong education in foundational math, science, and computer science. Programs can be adapted to increase preparation in IT domains and practices and meet the needs of IT professionals.

\subsection{New Courses}

Taking into account educational, economic, and political context in Latin America we suggest stronger emphasis in the following curricular areas to enhance the current version of the IT2007 report (version 0.61):

- Business and Technology Modeling. Nowadays IT is crucial to business processes in all organizations. That is why it is important that IT graduates are able to describe high-level solutions that integrate business processes with their supportive information technology resources and tools.

- IT Service Management and Operations. Service Management and Maturity frameworks such as ITIL [6] and CMMI for services [24] are relevant for all industries. They help align IT services to the needs of business, support their core processes, provide guidance on the use of IT as a 
facilitator of business change, transformation, growth, performance, and improvement towards maturity with increasing levels of customer satisfaction. In this proposal, we consider modifying a traditional 'Technical Support' course (semester 4) to include IT service processes [22] such as Service Desk and Incident Management [69], and adding a course on 'IT Service Management and Operations' (semester 6) that provides an overview of an IT Service Management framework with a focus on processes for IT service operations [77].

- Professional Ethics. In Section 3, we highlight the importance of digital data protection, privacy and security concerns, plus the existence of political, economic, and social instability in some Latin American countries.

- Cloud Computing. As there is a strong trend towards the use of the "cloud" and its prominent role information management at the organization level, we suggest students learn about challenges, issues, limitations, and risks of this technology.

- People Management. IT professionals have more crossfunctional responsibilities and manage a wide portfolio of resources. That is why we propose a course like 'People Management'.

- Large Data Management. The information that organizations manages and secures is growing every day (i.e., big data); therefore, management of large data topic becomes critical.

- Entrepreneurship and Innovation in Technology. Although entrepreneurship is not usually included in IT curricula in Latin America, many opportunities in promotion and support of startups are offered by governments and private companies. This suggests preparing students for innovation and entrepreneurship in order to get more opportunities in today's globalized world. The IT field evolves every day and new technologies are being invented and adopted. For example, the internet of things, mobile and cloud computing are domains which are becoming important recently. To enhance the collaboration between academia and employers of IT graduates, IT programs should include certifications that industry understands and appreciates.

\subsection{Proposed IT Program Structure}

Table 5.2 maps essential domains in the IT2017 v0.61 report to courses in the proposed IT program. The rows in Table 5.2 are the courses in the proposed program, and the columns correspond to the IT2017 v0.61 essential domains (spelled out in Appendix C). If a cell in the table is non-empty, then it contains one or more of the numbered subdomains from the domain covered in that course. For example, the entry 3, 4, 6-10 under the Global Professional Practice (GPP) domain indicates that this course covers the subdomains $3,4,6,7,8,9$, and 10 from the GPP essential IT domain.

Table 5.3 presents the structure of the proposed IT program, with course composition for each semester in the program of study.

\section{CONCLUSION}

Most countries in Latin America do not impose courses beyond the IT area, which allowed the authors of this paper to propose a curricular model that deals with relevant and challenging IT professional issues. The novelty of the proposed IT program stems from taking into account the importance of the following curriculum development decisions:
- Understanding the needs of a company by focusing coursework on modeling business domains;

- Modeling business processes together with the integrations of information technologies;

- Developing new courses in the areas of management of diverse teams, large data management, and technological innovation and entrepreneurship.

Table 5.2 Mapping proposed curricular model to the IT2017 essential domains

\begin{tabular}{|c|c|c|c|c|c|c|c|c|c|c|c|}
\hline $\begin{array}{r}\text { Essential } \\
\text { Domains } \\
\text { Courses } \\
\end{array}$ & $\begin{array}{l}\mathbf{C} \\
\mathbf{S} \\
\mathbf{P}\end{array}$ & $\begin{array}{l}\mathbf{G} \\
\mathbf{P} \\
\mathbf{P}\end{array}$ & $\begin{array}{l}\text { I } \\
\text { M } \\
\text { A }\end{array}$ & $\begin{array}{l}\mathbf{I} \\
\mathbf{S} \\
\mathbf{T}\end{array}$ & $\begin{array}{l}\mathbf{N} \\
\mathbf{E} \\
\mathbf{T}\end{array}$ & $\begin{array}{l}\mathbf{P} \\
\mathbf{E} \\
\mathbf{T}\end{array}$ & $\begin{array}{l}\mathbf{S} \\
\mathbf{A} \\
\mathbf{M}\end{array}$ & $\begin{array}{l}\text { S } \\
\text { I } \\
\text { A }\end{array}$ & $\begin{array}{l}\text { S } \\
\mathbf{W} \\
\mathbf{F}\end{array}$ & $\begin{array}{l}\mathbf{U} \\
\mathbf{X} \\
\mathbf{D}\end{array}$ & $\begin{array}{l}\text { W } \\
\text { M } \\
\text { S }\end{array}$ \\
\hline $\mathrm{CS}_{\mathrm{A}} 104$ & & & & & & & & & & & \\
\hline $\mathrm{CS}_{\mathrm{A}} 106$ & & & & & & & & & & & \\
\hline $\mathrm{CS}_{\mathrm{A}} 140$ & & & & & & & & & $\begin{array}{l}1- \\
4\end{array}$ & & \\
\hline $\mathrm{CS}_{\mathrm{A}} 141$ & & & & & & & & & 7 & & \\
\hline $\mathrm{CS}_{\mathrm{A}} 220$ & & & & & & & & & & & \\
\hline $\mathrm{CS}_{\mathrm{A}} 242$ & & & & & & & & & $\begin{array}{c}5- \\
6\end{array}$ & & \\
\hline$I T_{A} 280$ & 1 & 1 & 1 & 1 & 1 & 1 & 1 & 1 & & 1 & 1 \\
\hline $\mathrm{IT}_{\mathrm{A}} 300$ & & & & & & & & & & $\begin{array}{c}2- \\
8\end{array}$ & \\
\hline $\mathrm{IT}_{\mathrm{A}} 301$ & & & & & & & & $\begin{array}{c}2- \\
6\end{array}$ & & & \\
\hline$I T_{A} \mathbf{3 1 0}$ & $2-7$ & & & & & & & & & & \\
\hline $\mathrm{IT}_{\mathrm{A}} 315$ & & & & & & & $\begin{array}{c}2- \\
6\end{array}$ & & & & \\
\hline $\mathrm{IT}_{\mathrm{A}} \mathbf{3 2 0}$ & & & $\begin{array}{c}2- \\
4\end{array}$ & & & & & & & & \\
\hline $\mathrm{IT}_{\mathrm{A}} 331$ & & & & $\begin{array}{c}2- \\
6\end{array}$ & & & & & & & \\
\hline $\mathrm{IT}_{\mathrm{A}} 340$ & & & & & $\begin{array}{c}2- \\
7\end{array}$ & & & & & & \\
\hline $\mathrm{IT}_{\mathrm{A}} 360$ & & & & & & $\begin{array}{c}2- \\
5\end{array}$ & & & & & \\
\hline $\mathrm{IT}_{\mathrm{A}} 390$ & & & & & & & & & & & $\begin{array}{c}2- \\
7\end{array}$ \\
\hline $\mathrm{IT}_{\mathrm{A}} 410$ & $\begin{array}{l}8- \\
14\end{array}$ & & & & & & & & & & \\
\hline$I T_{A} 412$ & & $2-7$ & & & & & & & & & \\
\hline $\mathrm{IT}_{\mathrm{A}} 420$ & & & $\begin{array}{c}5- \\
7\end{array}$ & & & & & & & & \\
\hline $\mathrm{IT}_{\mathrm{A}} 490$ & & $\begin{array}{l}6- \\
10\end{array}$ & & & & & & & & & \\
\hline $\mathrm{IT}_{\mathrm{A}} 491$ & & $\begin{array}{l}8- \\
11 \\
\end{array}$ & & & & & & & & & \\
\hline IT $_{\mathrm{A}} 492$ & & $\begin{array}{c}3,4, \\
6- \\
10\end{array}$ & & & & & & & & & \\
\hline$I T_{A} 493$ & & 12 & & & & & & & & & \\
\hline $\mathrm{IT}_{\mathrm{A}} 6$ & & & & & 6- & & & & & & $2-$ \\
\hline $\mathbf{I T}_{\mathrm{A}} 7$ & & & $\begin{array}{l}1- \\
7\end{array}$ & & & & & & & & \\
\hline $\mathrm{IT}_{\mathrm{A}} \mathbf{8 0 0}$ & & $\begin{array}{l}4- \\
12\end{array}$ & 3 & & & & & $\begin{array}{c}2- \\
6\end{array}$ & & & \\
\hline $\mathrm{IT}_{\mathrm{A}} \mathbf{9 0 0}$ & & & & & & & $\begin{array}{l}1- \\
6\end{array}$ & & & & \\
\hline $\begin{array}{c}\text { Subdomains } \\
\text { Covered }\end{array}$ & $\begin{array}{l}1- \\
14\end{array}$ & $\begin{array}{l}1- \\
12\end{array}$ & $\begin{array}{l}1- \\
7\end{array}$ & $\begin{array}{c}1- \\
6\end{array}$ & $\begin{array}{l}1- \\
7\end{array}$ & $\begin{array}{l}1- \\
5\end{array}$ & $\begin{array}{l}1- \\
6\end{array}$ & $\begin{array}{c}1- \\
6\end{array}$ & $\begin{array}{c}1- \\
7\end{array}$ & $\begin{array}{c}1- \\
8\end{array}$ & $\begin{array}{l}1- \\
7\end{array}$ \\
\hline $\begin{array}{c}\text { Minimum } \\
\text { Essential } \\
\text { Hours }\end{array}$ & 40 & 25 & 40 & 20 & 35 & 15 & 20 & 20 & 30 & 20 & 25 \\
\hline
\end{tabular}


Table 5.3 Structure of the proposed IT program

\begin{tabular}{|c|c|c|c|c|c|}
\hline Course Code & Course Name & Credit & Course Code & Course Name & Credit \\
\hline \multicolumn{3}{|l|}{ Semester 1} & \multicolumn{3}{|l|}{ Semester 2} \\
\hline $\mathrm{CS}_{\mathrm{A}} 104$ & Discrete Structures & 3 & $\mathrm{CS}_{\mathrm{A}} 106$ & Digital Logic & 3 \\
\hline $\mathrm{CS}_{\mathrm{A}} 140$ & Computer Programming 1 & 4 & $\mathrm{CS}_{\mathrm{A}} 141$ & Computer Programming 2 & 4 \\
\hline MATH 113 & Differential Calculus & 4 & $\mathrm{IT}_{\mathrm{A}} 280$ & IT Fundamentals & 3 \\
\hline PH 103 & General Physics \& Lab & 3 & MATH 114 & Integral Calculus & 4 \\
\hline ENG 140 & English Language 1 & 3 & ENG 190 & English Language 2 & 3 \\
\hline \multicolumn{2}{|c|}{ Total Semester Credit Hours } & 17 & \multicolumn{2}{|c|}{ Total Semester Credit Hours } & 17 \\
\hline \multicolumn{3}{|c|}{ Semester 3} & \multicolumn{3}{|c|}{ Semester 4} \\
\hline $\mathrm{CS}_{\mathrm{A}} 220$ & Computer Organization & 4 & $\mathrm{IT}_{\mathrm{A}} 360$ & Operating Systems & 4 \\
\hline $\mathrm{CS}_{\mathrm{A}} 242$ & Data Structures & 4 & $\mathrm{IT}_{\mathrm{A}} 320$ & Introduction to Databases & 3 \\
\hline $\mathrm{IT}_{\mathrm{A}} 300$ & Human-Computer Interaction & 3 & $\mathrm{IT}_{\mathrm{A}} 315$ & Technical Support & 3 \\
\hline $\mathrm{IT}_{\mathrm{A}} 301$ & Project Management & 4 & STA 111 & Introduction to Probability \& Statistics & 3 \\
\hline MATH 227 & Linear Algebra and Differential Equations & 4 & ENG 4 & English Language 4 & 3 \\
\hline ENG 3 & English Language 3 & 3 & & & \\
\hline \multicolumn{2}{|c|}{ Total Semester Credit Hours } & 22 & \multicolumn{2}{|c|}{ Total Semester Credit Hours } & 16 \\
\hline \multicolumn{3}{|c|}{ Semester 5} & \multicolumn{3}{|c|}{ Semester 6} \\
\hline $\mathrm{IT}_{\mathrm{A}} 340$ & Computer Networks & 4 & $\mathrm{IT}_{\mathrm{A}} 420$ & Database Administration DBMS & 3 \\
\hline $\mathrm{IT}_{\mathrm{A}} 310$ & Cybersecurity Fundamentals & 4 & $\mathrm{IT}_{\mathrm{A}} 410$ & IT Security and Risk Management & 3 \\
\hline $\mathrm{IT}_{\mathrm{A}} 390$ & Web Systems & 3 & $\mathrm{IT}_{\mathrm{A}} 490$ & Learning \& Thinking \& Research & 1 \\
\hline SPA 201 & Expository Writing & 2 & ITA 9 & IT Service Management and Operations & 3 \\
\hline COM 207 & Communication Skills & 2 & ETH 1 & Professional Ethics & 2 \\
\hline ECO 100 & Engineering economics & 2 & SPA 104 & Language Skills & 2 \\
\hline $\mathrm{IT}_{\mathrm{A}} 800$ & Business \& Technology Modelling & 3 & ENG 208 & Technical Writing & 3 \\
\hline \multicolumn{2}{|c|}{ Total Semester Credit Hours } & 20 & \multicolumn{2}{|c|}{ Total Semester Credit Hours } & 17 \\
\hline \multicolumn{6}{|c|}{ Summer Semester } \\
\hline $\mathrm{IT}_{\mathrm{A}} 491$ & Practical Training & 1 & & & \\
\hline \multicolumn{2}{|c|}{ Total Semester Credit Hours } & 1 & & & \\
\hline \multicolumn{3}{|c|}{ Semester 7} & \multicolumn{3}{|l|}{ Semester 8} \\
\hline $\mathrm{IT}_{\mathrm{A}} 331$ & Fundamentals of n-Tier Architectures & 3 & $\mathrm{IT}_{\mathrm{A}} 493$ & Senior Project in Information Technology 2 & 4 \\
\hline $\mathrm{IT}_{\mathrm{A}} 412$ & IT Governance & 3 & $\mathrm{IT}_{\mathrm{A}} \mathrm{xxx}$ & IT Elective 2 & 3 \\
\hline $\mathrm{IT}_{\mathrm{A}} 492$ & Senior Project in Information Technology 1 & 2 & $\mathrm{IT}_{\mathrm{A}} \mathrm{xxx}$ & IT Elective 3 & 3 \\
\hline $\mathrm{IT}_{\mathrm{A}} 6$ & Cloud Computing & 4 & COM 3 & People Management & 2 \\
\hline BUS 100 & Introduction to Business Administration & 2 & $\mathrm{IT}_{\mathrm{A}} 7$ & Large Data Management & 2 \\
\hline $\mathrm{IT}_{\mathrm{A}} \mathrm{xxx}$ & IT Elective 1 & 3 & BUS 2 & Entrepreneurship and Innovation in Technology & 2 \\
\hline $\mathrm{IT}_{\mathrm{A}} 900$ & Quality Management Systems & 3 & & & \\
\hline \multicolumn{2}{|c|}{ Total Semester Credit Hours } & 20 & \multicolumn{2}{|c|}{ Total Semester Credit Hours } & 16 \\
\hline
\end{tabular}

Earlier, we indicated that the work in this paper centers on three research questions that guided and structure our study on:

1. Collaborative nature of IT between academia and employers in Latin America;

2. Status of professional practice and assessment in Latin America;

3. Current situation of IT degree programs in Latin America and the proposal of an ideal futuristic IT program for Latin America.

The results of the literature research and analysis of faculty and employer surveys show that there is notable alignment between faculty and employers' vision, expectations, and interest in pursuing effective collaborations. Realizing these aspirations will require more interaction and formally defined participation.

Regarding the implementation of professional practice in the IT programs of study, here again, more interaction between academia and employers is a necessity. Perhaps the realization of a futuristic IT curriculum as proposed in Section 5 would be a crucial step in making IT programs at Latino universities more robust to prepare its graduates for promising careers in the field and to benefit countries in Latin America.

\section{ACKNOWLEDGEMENTS}

The IT2017 task group is most grateful and appreciating to ACM and its Education Board for its ongoing support for this project, especially providing a path for conducting and analyzing surveys in support of this work and the IT2017 project. 


\section{REFERENCES}

[1] Accreditation Criteria. Accreditation Board for Engineering and Technology. Retrieved July 13, 2016 from http://www.abet.org/.

[2] ACM/IEEE-CS Joint Task Force on Computing Curricula. 2005. The Overview Report: covering undergraduate degree programs in Computer Engineering, Computer Science, Information Systems, Information Technology, and Software Engineering. ACM Press and IEEE Computer Society Press.

[3] ACM/IEEE-CS Joint Task Force on Computing Curricula. 2008. Information Technology 2008: Curriculum Guidelines for Undergraduate Programs in Information Technology. ACM Press and IEEE Computer Society Press.

[4]. Alvarez and C. Gutierrez. 2012. History of Computing in Chile. IEEE Annals of the History of Computing, 34, 3, (July-Sept., 2012), 2223.

[5] Asociación de Empresas de Tecnologías de Información y Comunicaciones de Querétaro. 2016. Retrieved June 20, 2016 from http://www.inteqsoft.com.mx/.

[6] Axelos. 2016. What is ITIL ${ }^{\circledR}$ Best Practice? Retrieved August 27, 2016 from https://www.axelos.com/best-practice-solutions/itil/what-isitil

[7] Baeza-Yates, R.A., Fuller, D.A., Pino, J. A., and Goodm, S. E. 1995. Computing in Chile: The Jaguar of the Pacific Rim? Communications of the ACM, 38, 9, (September1995), 23-28.

[8] CAMTIC. 2011. Costa Rica: Verde e Inteligente 2.0 ®. San José, Costa Rica: CAMTIC.

[9] CAMTIC. 2015. Mapeo sectorial de tecnologías digitales 2014. San José, Costa Rica: CAMTIC \& PROCOMER.

[10] CareerBuilder Harris Poll. 2015. Companies Planning to Hire More Recent College Graduates. CareerBuilder Survey Press Release (April 23).

[11] A. J. Carnota. 2015. The Beginning of Computer Science in Argentina and the Calculus Institute, 1957 - 1970. IEEE Annals of the History of Computing, 37, 4, 40-52.

[12] CEDEFOP. 2008. Terminology of European education and training policy. A selection of 100 key terms. Luxembourg: Office for Official Publications of the European Communities.

[13] Chávez, A., Martínez, M., \& Cano, R. 2014. Proyectos integradores como estrategia didáctica para fortalecer las competencias de aprendizaje en los estudiantes del Instituto Tecnológico de Colima. Casos y experiencias compartidas en las ciencias, 199-203.

[14] Chiluiza, K. et al. 2014. En búsqueda de la acreditación ABET: Estrategias exitosas en una institución de educación superior pública de Sudamérica. In the Proceedings of the Twelfth Latin American and Caribbean Conference for Engineering and Technology (LACCEI'2014). July 22 - 24, 2014, Guayaquil, Ecuador.

[15] CINDE. 2008. Encuesta Recursos Humanos 2008. San José, Costa Rica: Coalición Costarricense de Iniciativas de Desarrollo.

[16] CINDE. 2014. The Talent Place. Retrieved June 20, 2016 from http://www.thetalentplace.cr/.

[17] CINDE. 2011. Estudio de necesidades de talento humano de las empresas de Inversión Extranjera Directa. San José, Costa Rica: Coalición Costarricense de Iniciativas de Desarrollo.

[18] CINDE. 2014. Análisis de brechas en Tecnologías de Información. San José, Costa Rica: CINDE.

[19] Cinterfor. 2015. Aprendizaje y políticas de transición de la educación al trabajo para jóvenes en Costa Rica, Guatemala y México. Montevideo, Uruguay: Centro Interamericano para el Desarrollo del Conocimiento en la Formación Profesional (Cinterfor), Organización Internacional del Trabajo (International Labour Organization).

[20] Cisco. 2008. Habilidades en redes en Latinoamérica: ¿Un desafio futuro? San Francisco, United States of America: Cisco Systems.
[21] Cluster de Integradores de Alta Tecnología - Jalisco. 2016. Retrieved June 20, 2016 from http://www.cncs.mx/cncsnet/DisplayCluster.aspx?idCluster=25.

[22] CMMI Product Team. 2010. CMMI ${ }^{\circledR}$ for Services, Version 1.3. Improving processes for providing better services. Pittsburgh, USA: Software Engineering Institute, Carnegie Mellon University.

[23] CompTIA 2012a. State of the IT Skills Gap. International Summary. Downers Grove, United States of America: Computing Technology Industry Association.

[24] CompTIA 2012b. State of the IT Skills Gap. Full Report. Downers Grove, United States of America: Computing Technology Industry Association.

[25] CompTIA 2014. State of IT Skills Gap - 2014 Summary. Downers Grove, United States of America: Computing Technology Industry Association.

[26] Council of Europe. 2016. Common European Framework of Reference for Languages. Strasbourg, France: Council of Europe (Language Policy Division). Retrieved June 20, 2016 from http://www.coe.int/t/dg4/linguistic/source/framework_en.pdf.

[27] Ivan da Costa Marques. 2015. History of computing in Latin America. IEEE Annals of the History of Computing, 37, 4, pp. 10-12.

[28] Costa Rica Multilingüe. 2009. Informe 1er año de labores. Programa Costa Rica Multilingüe. San José, Costa Rica: Fundación Costa Rica Multilingüe. Retrieved June 20, 2016 from www.teachenglishcostarica.com/resorces/Informe\%20Anual\%20CRML. pdf.

[29] J. Domingues, J. C. Acosta-Guadarrama, R. M. Valdovinos, V. H. Solis, N. Plata, L. Quintanar and R. Davila. 2015. A Brief History of Computing in Mexico. IEEE Annals of the History of Computing, 37, 4, 76-86.

[30] Duale Hochschule Latinoamérica. 2011. Documento Síntesis. Fundamentos, Principios y Funcionamiento. Bucaramanga, Colombia: Red de Universidades Empresariales de América Latina, Berufsakademie, según el Modelo de Baden-Württemberg, Alemania.

[31] Duale Hochschule Baden-Württemberg. 2016. BadenWuerttemberg Cooperative State University. Retrieved June 20, 2016 from http://www.dhbw.de/english/home.html.

[32] Experis. 2013. Tomorrow's Talent: Plugging the IT Skills Gap. London, United Kingdom: Experis.

[33] García, J. M. 2006. La ética como asignatura en los estudios de informática. Retrieved June 20, 2016 from http://ditec. um. es/ jmgarcia/papers/etica.pdf.

[34] Guevara, Miguel \& Gamboa, Oscar. 2009. Experiencias de incorporación de emprendedurismo en Instituciones de Educación Superior. ICAP-Revista Centroamericana de Administración Pública (56-57): 171-182. San José, Costa Rica.

[35] Gutiérrez, F. L. 2015. Experiencia en la facilitación de los aprendizajes de la asignatura liderazgo y ética informática para ingenieros en sistemas de información. Revista Multi-Ensayos, 1, 2, 107 113.

[36] Hanushek, Eric. 2012. Dual education - Europe's secret recipe. CESifo Forum: a quarterly journal on European economic issues, 13, 3, 29-34.

[37] Hart Research Associates, 2015. Falling Short? College Learning and Career Success, Washington, DC: Association of American Colleges and Universities.

[38] IDC. 2013. Networking Skills in Latin America (2013). Mexico, D.F., Mexico: IDC, sponsored by Cisco Systems.

[39] IDC. 2016. Networking Skills in Latin America (2016). Mexico, D.F., Mexico: IDC, sponsored by Cisco Systems.

[40] J. Impagliazzo, J. Araoz, B. Baran, J. Contreras, A P. Sanjuan, R. Puigjaner. 2006. Evolution of Computing in Spanish-Speaking Countries (A Panel Presentation). In History of Computing and Education 2, (Boston: Springer, 2006), 49-57. 
[41] Inter-American Development Bank. 2010. Using technology to increase competitiveness of small and medium-sized companies. Washington, D.C., United States of America: Inter-American Development Bank.

[42] ITIL Processes. 2016. Retrieved June 20, 2016 from http://wiki.en.it-processmaps.com/index.php/ ITIL_Processes.

[43] P. M. Jacovkis. 2006. The First Decade of Computer Science in Argentina. In History of Computing and Education 2, (Boston-Springer, 2006), 181-191.

[44] Lee, P., Stewart, D., Calugar-Pop, C. 2016. Women in IT. Technology, Media, and Telecommunication Predictions 2016. Deloitte Touche Tohmatsu Limited, UK: London.

[45] López Rodríguez, N. M. 2012. El proyecto Integrador: Estrategia didáctica para la formación de competencias desde la perspectiva del enfoque socioformativo. México: Gafra Editores.

[46] Manpower. 2015. 2015 Talent Shortage Survey Report. Milwaukee, United States of America: ManpowerGroup.

[47] Mata, F. and Jofré, A. 2001. Estudio de oferta y demanda del recurso humano en el sector software de Costa Rica. San José: Prosoftware, Bid-Caprosoft-Procomer-Funcenat.

[48] Mata, F. and Matarrita, R. 2008. Determinantes de una industria basada en el conocimiento, el sector TIC en Costa Rica: Los procesos de formación como fuente de sostenibilidad y generación de empleo. Componente de oferta y demanda. San José, Costa Rica: CAMTIC.

[49] Mata, F. J., Matarrita, R., Araya, E. 2003. Hacia una Estrategia para el Fortalecimiento del Capital Humano para la Industria de Desarrollo de Software: Conclusiones y Recomendaciones del Estudio de Fortalecimiento de los Centros de Enseñanza y la Actualización Curricular. Programa de Apoyo a la Competitividad del Sector de Desarrollo de Software de Costa Rica (Pro-Software). October, 2003.

[50] Mata, F. et al. 2012. Assessing Computer Education in Costa Rica: Results of a Supply and Demand Study of ICT Human Resources. CLEIej, 15,1 .

[51] Matarrita, R., Mata, F. J., Araya, E. 2003. Catálogo de perfiles ocupacionales para el desarrollo de software. Estudio de Fortalecimiento de los Centros de Enseñanza en Computación e Informática y la Actualización Curricular: Programa de Apoyo a la Competitividad del Sector de Desarrollo de Software de Costa Rica (Pro-Software). Now CAMTIC.

[52] F. Y. Mesa Jiménez. 2012. Las Tecnologías de la Información ya la Comunicación en la Universidad Colombiana: Evolución y Prospectica. Revista Historia de la Educación Latinoamericana, 14, 19.

[53] Monge-González, R., and Hewitt, J. 2010. Innovation, $R \& D$ and Productivity in the Costa Rican ICT Sector: A Case Study. IDB working paper series, No.189. Washington, D.C., United States of America: Inter-American Development Bank.

[54] Multilateral Investment Fund. 2010. The Software Industry in Uruguay. Washington, D.C., United States of America: Multilateral Investment Fund. Retrieved June 20, 2016 from http://www.fomin.org/ Home/Impact/ImpactEvaluations/SoftwareIndustry.aspx.

[55] Nicholson, B. and Sahay, S. 2007. Software Exports Development in Costa Rica: Contradictions and the Potential for Change. In Proceedings of the 9th International Conference on Social Implications of Computers in Developing Countries, São Paulo, Brazil, May 2007.

[56] National Research Council. 2012. Education for Life and Work: Developing Transferable Knowledge and Skills in the $21^{\text {st }}$ Century. Committee on Defining Deeper Learning and $21^{\text {st }}$ Century Skills, J.W. Pellegrino and M.L. Hilton, editors. Washington, DC: The National Academic Press.

[57] Parra, B.J. 2013. Proyecto integrador como estrategia formativa para el fortalecimiento de competencias específicas y transversales en la facultad de ingeniería. In Proceeding of the $7^{\text {th }}$ World Engineering Education Forum, Cartagena de Indias, Colombia.

[58] de la Peña, J. R., Borrero, L. L., García, M. R. C., \& Expósito, F. R. (2012). El proyecto integrador como experiencia didáctica en la formación del ingeniero informático: Universidad de Holguín, Cuba (UHOLM). Escenarios, 10(1), 106-115.

[59] Pinto, C. and Herrera, R. (Eds). 2009. Formación de capital humano en el sector de TIC en Costa Rica. Mexico: FLACSO México.

[60] Pires, S. and Lemaitre, M. J. 2008. Sistemas de acreditación y evaluación de la educación superior en América Latina y el Caribe. In Conferencia Regional de Educación Superior.

[61] Rama, C. 2009. El nacimiento de la acreditación internacional. In Revista da Avaliação da Educação Superior, 14, 2, 291-311.

[62] Reif, H.L., Mathieu R.G. 2009. Global Trends in Computing Accreditation. Computer, 42, 11, 102-104.

[63] Romero, A. I. T., Martínez, C. B., López, F. G. L., \& Murillo, J. G. M. 2014. Proyectos integradores: estrategia didáctica para el desarrollo de competencias en la Universidad Tecnológica de Chihuahua. Estudio de caso.

[64] Russell, J. 2003. Global Accreditation Trends. In Proceedings of the International Conference on Engineering Education. Valencia, Spain, 21-25.

[65] Sabin, M., Impagliazzo, J., Alrumaih, H., Byers, B., Gudoniene, D., Hamilton, M., Kotlyarov, V., Lunt, B., McGuffee, J.M, Peltsverger, S., Tang, C., Viola, B., and Zhang, M. 2015. Multinational Perspectives on Information Technology from Academia and Industry. In Proceedings of the 2015 ITiCSE on Working Group Reports (ITICSE-WGR '15). ACM, New York, NY, USA, 149-171. DOI=http://dx.doi.org/10.1145/ 2858796.2858802

[66] Sabin, M., Snow, P., and Impagliazzo, J. 2016. Towards the Internationalization of Curriculum Guidelines for Undergraduate IT Degree Programs. In Proceedings of Society for Information Technology \& Teacher Education International Conference 2016 (SITE'16), pp. 1126-1133. Chesapeake, VA: Association for the Advancement of Computing in Education (AACE).

[67] Sabin, M., Snow, P., and Viola, B. 2016. Industry and faculty surveys call for increased collaboration to prepare information technology graduates. J. Comput. Sci. Coll. 31, 6 (June 2016), 70-78.

[68] S. Seidman. 2014. Computing: An Emerging Profession? ACM Inroads, 5, 4, (December 2014), 6-11.

DOI=http://dx.doi.org/10.1145/2644826.

[69] Service Desk and Incident Management. 2016. Retrieved June 20, 2016 from http://wiki.en.it-

processmaps.com/index.php/Service_Desk_and_Incident_Management.

[70] SG Buzz. 2016. Se establece el Consejo Nacional de Clústeres de Software y TICs CANIETI. Retrieved June 20, 2016 from http://sg.com.mx/content/view/1125.

[71] Tobón, S. and Mucharraz, G. 2010. El modelo de competencias en las prácticas docentes: Hacia escenarios significativos de vida. México: Conrrumbo

[72] The Catalist. 2011. Mexico is an Information Powerhouse (October 15, 2011). Retrieved June 20, 2016 from http://thecatalist.org/2011/10/mexico-is-an-information-technologypowerhouse/.

[73] Trejos, I. 2001. Cenfotec: educación de calidad para la industria de software. ALTEC 2001, IX Seminario Latino-Iberoamericano de Gestión Tecnológica. Innovación Tecnológica en la Economía del Conocimiento. Costa Rica.

[74] Trejos, I. 2010. Educación tecnológica. El Financiero No. 751.

[75] Trejos, I. and Sancho, L. 2011. Descriptive Country Summary, Costa Rica. IEEE Workshop on Common Nomenclature for ComputingRelated Programs in Latin America. Lima, Perú: Institute of Electrical and Electronics Engineers.

[76] Trejos, A. et al. 2012. Desarrollo del Talento humano: la clave para competir en la atracción de la inversión extranjera directa. San José, Costa Rica: INCAE y CINDE.

[77] TSO. 2011. ITIL Service Operation (Vol. ITIL). Norwich, United Kingdom: The Stationery Office. 
[78] UNESCO. 2014. Dual Education System. Paris, France: UNESCO.

[79] University of Waterloo. 2016. Co-operative education. Retrieved June 20, 2016 from https://uwaterloo.ca/co-operative-education/aboutco-operative-education.

[80] World Economic Forum. 2016. The Future of Jobs. Employment, Skills and Workforce Strategy for the Fourth Industrial Revolution. Geneva, Switzerland: World Economic Forum.

\section{APPENDIX}

\section{Appendix A Web Search References of IT-related Programs in Latin America}

Benemérita Universidad Autónoma de Puebla (Mexico). 2016. Undergraduate program in licentiate in information technology engineering. Retrieved June 20, 2016 from

http://cmas.siu.buap.mx/portal_pprd/wb/EDUCATIVA/

ingenieria_en_tecnologias_de_la_informacion.

Centro Universitário de Brasília. 2016. Governança em Tecnologia da Informação. Retrieved June 20, 2016 from

https://www.uniceub.br/cursos/tecnologia/pos-graduacao/governancaem-tecnologia-da-informacao/sobre-o-curso.aspx.

Instituto Tecnológico Autónomo de México (México). 2016. Maestría en Tecnologías de Información y Administración. Retrieved June 20 , 2016 from http://mtia.itam.mx/.

Tecnológico de Monterrey, México, Maestría en Administración de Tecnologías de Información, Retrieved June 20, 2016 from $\mathrm{http}: / / \mathrm{www}$. itesm.mx/wps/wcm/connect/

itesm/tecnologico + de + monterrey/maestrias $+\mathrm{y}+$ doctorados/escuelas/prog ramas + de + negocios + en + linea/maestria + en + administracion + de + tecnolog ias + de+informacion/en+linea + mti-v.

Universidad Alas Peruanas (Peru). 2016. Undergraduate program in systems and informatics engineer. Retrieved June 20, 2016 from http://www.uap.edu.pe/Esp/

ProgramacionAcademica/Pregrado/02/Inicio.aspx.

Universidad Andina del Cusco (Peru). 2016. Undergraduate program in information systems engineer. Retrieved June 20, 2016 from http://www.uandina.edu.pe/index.php/ ingenieria-de-sistemas/.

Universidad Austral de Chile. 2016. Undergraduate program in Ingeniería en Información y Control de Gestión. Retrieved June 20, 2016 from http://www .pmontt.uach.cl/ingenier\%C $3 \% \mathrm{AD}$-eninformaci $\% \mathrm{C} 3 \% \mathrm{~B} 3 n$-y-control-de-gesti $\% \mathrm{C} 3 \% \mathrm{~B} 3 n$-se-parte-deldesarrollo-e-innovacion-del-pais.

Universidad Autónoma de Nuevo León (Mexico). 2016. Undergraduate program in licentiate in information technology. Retrieved June 20, 2016 from http://www.uanl.mx/content/licenciado-en-tecnologias-de-lainformacion

Universidad Católica de Uruguay (Uruguay). 2016. Undergraduate program in informatics engineer. Retrieved June 20, 2016 from http://carreras.ucu.edu.uy/index.php/carreras/ingenieria-ytecnologias/ingenieria-en informatica?_ga=1.7884858.94907089.1468430622.

Universidad Cenfotec (Costa Rica). 2016. Undergraduate program in information technology and systems engineer,. Retrieved June 20, 2016 from https://www.ucenfotec.ac.cr/ carreras/adm-de-sist/.

Universidad de Bogotá Jorge Tadeo Lozano (Colombia). 2016. Undergraduate program in systems and informatics engineer. Retrieved June 20, 2016 from http://www.utadeo.edu.co/es/facultad/cienciasnaturales-e-ingenieria/ programa/layout-1/ingenieria-de-sistemas.

Universidad de Chile (Chile). 2016. Master program in Magíster en Tecnologías de la Información. Retrieved June 20, 2016 from http://www.uchile.cl/postgrados/50703/ tecnologias-de-la-informacion.

Universidad de Cuenca (Ecuador). 2016. Master in Gestión Estratégica de Tecnologías de la Información. Retrieved June 20, 2016 from http://www.ucuenca.edu.ec/la-oferta-academica/oferta-degrado/facultad-de-ingenieria/posgrados/maestria-ing-1.

Universidad de Guadalajara (México). 2016. Maestría de las Tecnologías de la Información. Retrieved June 20, 2016 from http://www.udg.mx/es/oferta-academica/posgrados/ maestrias/maestriaen-tecnologias-de-informacion-cucea,

Universidad de Insurgentes. 2016. Undergraduate program of Licenciatura Tecnologías de la Información. Retrieved June 20, 2016 from http://www .universidadinsurgentes.edu.mx/tecnologias-de-lainformacion/.

Universidad de los Andes (Colombia). 2016. Undergraduate program in computer and systems engineering. Retrieved June 20, 2016 from https://sistemas.uniandes.edu.co/ es/isis-descripcion/informaciongeneral-pregrado.

Universidad de Palermo (Argentina). 2016. Maestría en Tecnología de Información. Retrieved June 20, 2016 from

http://www.palermo.edu/ingenieria/maestria-en-tecnologia-de-lainformacion/index.html.

Universidad de Palermo (Argentina). 2016. Undergraduate program in licentiate in information technology. Retrieved June 20, 2016 from http://www.palermo.edu/ingenieria/ lic-en-tecnologia-de-lainformacion/index.html.

Universidad de Talca. 2016. Undergraduate program in business informatics engineer. Retrieved June 20, 2016 from http://iie.utalca.cl/.

Universidad del Valle de México. 2016. Undergraduate program Licenciatura en Desarrollo de Tecnologías de Información (bachelor in development in IT) - Laureate International Universities (Mexico). Retrieved June 20, 2016 from

http://www.universidaduvm.mx/licenciatura-en-desarrollo-detecnologias-de-informacion/.

Universidad ESAN (Peru). 2016. Undergraduate program in information technology and systems engineer. Retrieved June 20, 2016 from http://www.ue.edu.pe/ingenieria-de-tecnologias-de-informacion-ysistemas/plan-de-estudios

Universidad Iberoamericana (Dominican Republic). 2016.

Undergraduate program in information and communications technology engineer (ICT). Retrieved June 20, 2016 from

http://www.unibe.edu.do/en/carrera/ingenieria-tic.

Universidad Internacional Tres Fronteras (Parahuay]). 2016. Magíster en Dirección Estratégica en Tecnologías de la Información. Retrieved June 20, 2016 from https://www. uninter.edu.py/postgrados/ciencias-ytecnologia/magister-en-direccion-estrategica-en-tecnologias-de-lainformacion.

Universidad Nacional Abierta y a Distancia (Colombia). 2016. Master in Gestión de Tecnología de Información. Retrieved June 20, 2016 from https://estudios.unad.edu.co/ maestria-en-gestion-de-tecnologia-deinformacion.

Universidad San Francisco de Quito (Ecuador). 2016. Undergraduate program in Ingeniería de Sistemas. Retrieved June 20, 2016 from http://www.usfq.edu.ec/

programas_academicos/colegios/politecnico/carreras/Paginas/ingenieria _en_sistemas.aspx.

Universidad Santa María - Sede Posgrado (Venezuela]). Master in gerencia en tecnologías de la información. Retrieved June 20, 2016 from http://www.usm.edu.ve/

usmpostgrado/index.php?option $=$ com_content $\&$ view $=$ article $\& \mathrm{id}=235 \& \mathrm{I}$ temid $=349$.

Técnica Nacional (Argentina), 2016. Undergraduate program in information systems engineer. Retrieved June 20, 2016 from http://www.topuniversities.com/universities/universidadtecnol $\% \mathrm{C} 3 \% \mathrm{~B} 3$ gica-nacional-utn.

Universidad Tecnológica Boliviana (Bolivia). 2016. Undergraduate program in systems engineer. Retrieved June 20, 2016 from http://www.utb.edu.bo/index.php/carreras/ingenieria-de-sistemas. 


\section{Appendix B Surveys}

\section{B1 Faculty Survey}

F1 In which country is the main campus of your academic institution located?

F2 What is your gender?

F3 How many students are enrolled in your academic institution? Five ranges offered.

F4 How many students are enrolled in all computing programs within your department?

F5 Is your department currently collaborating or partnering with employers in efforts to make your undergraduate information technology programs more responsive to their workplace needs?

F6 In your department, what non-technical workplace skills are considered most important for IT students to have when they graduate from your undergraduate information technology program? Please choose at most six of the listed skill sets, or choose "Other" and at most five of the listed skill sets. Thirteen options offered, including 'Other'.

F7 In what ways is your department most likely to collaborate with employers to improve students' workplace-relevant skills (technical and non-technical)? Choose all that apply. Nine options offered, including 'Other'.

F8 What mainly motivates your department to develop and sustain collaborations with employers of your IT graduates? Choose all that apply. Five options offered, including 'Other'.

\section{B2 Employer Survey}

E1 In which country is your organization located?

E2 Which of the following best describes your title?

E3 What is your gender?

E4 How many full-time employees does your organization have? Seven options offered.

E5 What is the economic sector of your organization?

E6 Is your organization currently collaborating or partnering with computing departments at universities in efforts to make their undergraduate information technology programs more responsive to your workplace needs?

E7 At your organization, what non-technical workplace skills are considered most important for employers to have when they join your organization? Please choose at most six of the listed skill sets, or choose "Other" and at most five of the listed skill sets. Thirteen options offered, including 'Other'.

E8 At your organization, what non-IT functional areas have the highest needs for competent IT graduates? Please choose at most four of the listed areas, or choose Other and at most three of the listed areas. Eleven options offered, including 'Other'.

E9 In what way is your organization most likely to collaborate with academic institutions to improve students' workplace-relevant skills (technical and non-technical)? Choose all that apply. Nine options offered, including 'Other'.

E10 What mainly motivates your organization to develop and sustain collaborations with academic institutions? Choose all that apply. Five options offered, including 'Other'.

\section{B3 Non-technical Workplace Skills}

Prompted answers for Faculty Survey question F6 and Employer Survey question E7

\begin{tabular}{|cl|}
\hline 1. & Analyzing and solving complex problems \\
\hline 2. & Collaborating with people from different backgrounds \\
\hline 3. & Critical and analytical thinking \\
\hline 4. & Empathy and sensitivity to others \\
\hline
\end{tabular}

\begin{tabular}{|ll|}
\hline 5. & Ethical reasoning \\
\hline 6. & Negotiation \\
\hline 7. & Planning and organizational \\
\hline 8. & Professional networking \\
\hline 9. & Proficiency in more than one language \\
\hline 10. & Self-reflection \\
\hline 11. & Working in teams \\
\hline 12. & Other (please specify) \\
\hline
\end{tabular}

\section{Appendix C IT2017 v0.61 Essential IT Domains}

The IT2017 v0.61 curricular framework has eleven essential IT domains as shown below:

\begin{tabular}{|l|l|}
\hline CSP & Cybersecurity Principles \\
\hline GPP & Global Professional Practice \\
\hline IMA & Information Management \\
\hline IST & Integrated Systems Technology \\
\hline NET & Networking \\
\hline PFT & Platform Technologies \\
\hline SWF & Software Fundamentals \\
\hline SAM & System Administration and Maintenance \\
\hline SIA & System Integration and Architecture \\
\hline UXD & User Experience Design \\
\hline WMS & Web and Mobile Systems \\
\hline
\end{tabular}

Each essential domain is further described by a domain scope statement and list of subdomains. Information about the IT2017 v0.61 curricular framework can be found online at http://it2017.acm.org. 